\title{
Analytical characterisation of nanoscale zero-valent iron: An illustrated methodological review
}

\author{
L. Chekli, ${ }^{a, b}$ B. Bayatsarmadi, ${ }^{c}$ R. Sekine, ${ }^{d}$ B. Sarkar, ${ }^{b, d}$ A. Maoz Shen, ${ }^{d}$ K.G. Scheckel, ${ }^{e}$ W. Skinner, ${ }^{f}$ \\ R. Naidu, ${ }^{b, d}$ H.K. Shon ${ }^{a, b}$ E. Lombi, ${ }^{d}$ and E. Donner, ${ }^{b, d}$ \\ a School of Civil and Environmental Engineering, University of Technology, Sydney, Post Box 129, \\ Broadway, NSW 2007, Australia. \\ ${ }^{b}$ CRC CARE, PO Box 486, Salisbury, SA 5106, Australia.
}

'School of Chemical Engineering, The University of Adelaide, Engineering North Building, Adelaide, SA 5005, Australia.

${ }^{d}$ Centre for Environmental Risk Assessment and Remediation, University of South Australia, Building X, Mawson Lakes Campus, SA 5095, Australia.

e U.S. Environmental Protection Agency, National Risk Management Research Laboratory, Land Remediation and Pollution Control Division, 5995 Center Hill Avenue, Cincinnati, OH, USA.

${ }^{f}$ Ian Wark Research Institute, University of South Australia, Building IW, Mawson Lakes Campus, SA 5095, Australia.

*Corresponding author: Email: Enzo.Lombi@unisa.edu.au; Phone: (61) 883026267.

\begin{abstract}
Zero-valent iron nanoparticles (nZVI) have been widely tested as they are showing significant promise for environmental remediation. However, many recent studies have demonstrated that their mobility and reactivity in subsurface environments are significantly affected by their tendency to aggregate. Both the mobility and reactivity of nZVI mainly depends on properties such as particle size, surface chemistry and bulk composition. In order to ensure efficient remediation, it is crucial to accurately assess and understand the implications of these properties before deploying these materials into contaminated environments. Many analytical techniques are now available to determine these parameters and this paper provides a critical review of their usefulness and limitations for nZVI characterisation. These analytical techniques include microscopy and light scattering techniques for the determination of particle size, size distribution and aggregation state, and X-ray techniques for the characterisation of surface chemistry and bulk composition. Example characterisation data derived from commercial nZVI materials is used to further illustrate method strengths and limitations. Finally, some important challenges with respect to the characterisation of $\mathrm{nZVI}$ in groundwater samples are discussed.
\end{abstract}

Keywords: zero-valent iron nanoparticles, characterization techniques, particle size, surface chemistry, bulk composition, groundwater remediation. 


\section{Introduction}

In recent years, manufactured nanoparticles (MNPs) have attracted increasing interest for their potential applications in the treatment of contaminated soil and water. In comparison to traditional macro- and micro-scale materials, MNPs possess significantly higher surface-to-volume ratios, which frequently translate into unexpected surface effects and unique beneficial properties. In addition, by virtue of their small size, MNPs can potentially be used directly in the field for in situ treatment via injection at almost any location and depth in soil and groundwater systems [1]. Ideally, for this type of application, MNPs are expected to feature several key properties including: (i) high reactivity for the removal of targeted contaminants; (ii) high mobility in porous media (i.e. aquifers, soil); (iii) high reactive longevity after injection and (iv) low toxicity to the biota in the surrounding environment [1]. These properties are the main drivers when designing MNPs for the purpose of soil and groundwater remediation. However, it is quite clear that in practice some of these properties are difficult if not impossible to achieve simultaneously. For instance, high reactivity usually translates to short longevity, and potentially greater ecotoxicological impact. In addition, these nanoparticles must also be produced and delivered at a cost that remains sufficiently low to compete with conventional technologies.

Due to their purportedly low cost, highly reactive surface sites and high in-situ reactivity, the most widely studied MNPs for environmental remediation are nanoscale zero-valent iron (nZVI) [2-4]. Although most of the lab-scale, pilot-scale and field demonstration studies targeted soil and groundwater remediation, nZVI has also been successfully applied for the stabilization of biosolids [5], the removal of phosphorus [6, 7], the decoloration of dyes [8,9], as a membrane anti-fouling agent [10] and for the treatment of nuclear waste, explosives and herbicides [11-13].

Many studies suggested a core-shell structure for $n Z V I[14,15]$ as illustrated in

Figure 1. The core consists primarily of zero-valent iron while the mixed valent oxide shell resulted from the oxidation of the core metallic iron [16]. nZVI materials have been shown to exhibit high 
reactivity in remediating aquifers contaminated by non-aqueous phase liquids (NAPL) and many other hazardous compounds $[3,17,18]$.

\section{Figure 1}

Effectively delivering the nZVI to the contaminant source zone is essential for the success of in situ $n Z V I$ remediation. However, there are currently a number of issues limiting the potential effectiveness of nZVI for this application. In fact, many laboratory and pilot-scale field studies have demonstrated that the mobility and reactivity of nZVI are substantially limited in natural porous systems such as soils and also groundwater aquifers [19-22]. The limited mobility and reactivity can be explained by three basic mechanisms [23-25]:

- Due to their magnetic properties [26], nZVI particles have a natural tendency to aggregate which generates significant losses in reactivity and decreases environmental mobility [27];

- As nZVI are prone to surface oxidation, the formation of corrosion product precipitates (including $\mathrm{Fe}(\mathrm{OH})_{2}, \mathrm{Fe}(\mathrm{OH})_{3}, \mathrm{Fe}_{3} \mathrm{O}_{4}, \mathrm{Fe}_{2} \mathrm{O}_{3}, \mathrm{FeOOH}, \mathrm{Fe}_{5} \mathrm{HO}_{8} .4 \mathrm{H}_{2} \mathrm{O}$ and green rusts) considerably limit direct $\mathrm{Fe}^{0}$-contaminant interactions [1].

- Due to interaction with the subsurface environment (mainly via attachment to mineral surfaces and carbonaceous materials or microbial removal), nZVI may rapidly become inert and relatively immobile [19].

These different factors (i.e. magnetic characteristics, tendency to aggregate, surface oxidation and interaction with the environment) and related limitations mainly depend on nZVI properties such as particle size, surface charge, bulk composition and surface chemistry. Furthermore, these properties change with time due to the reactive nature of the materials. Therefore, it is essential to thoroughly characterise newly developed products when reporting results in the literature, and also to compare the characterisation results for commercial products with the manufacturers' specifications.

Although some studies have previously focused on the characterisation of nZVI $[28,29]$, it is increasingly recognised that the characterisation approaches used for MNPs are frequently 
inadequate and/or underdeveloped. Moreover, multiple and complimentary analytical methods are needed [30] as the validity and accuracy of some results may be inadequate under some conditions [31]. The purpose of this review is to present the different analytical tools available to characterise the different properties of $\mathrm{nZVI}$ and to discuss their advantages and limitations. Properties taken into consideration include particle size, particle charge, bulk composition and surface chemistry. Examples of characterisation methods of commercial nZVI/ZVI will be also provided. Finally, the challenges of characterising $\mathrm{nZVI}$ in groundwater will be also discussed.

\section{Particle size, size distribution and aggregation state analysis}

Particle size, size distribution and aggregation state are important parameters to evaluate before deploying $\mathrm{nZVI}$ in the subsurface environment to ensure efficient site remediation. Many studies have demonstrated that both the reactivity and mobility of metal nanoparticles can be dependent on particle size [14, 32, 33]. For instance, a recent study by Signorini et al. [34] demonstrated that the composition of the oxide shell, which significantly impacts on nZVI reactivity [35], is influenced by the size of the particle. Another important characteristic of $n Z V I$ particles that can impact on their remediation efficiency is their strong tendency to aggregate due to their magnetic properties and tendency to remain in the most thermodynamically favourable state $[36,37]$. Importantly, the formation of highly aggregated particles will reduce the available reactive surface sites compared to dispersed nano-sized particles [14].

Several analytical methods are available to measure the particle size, size distribution and aggregation state of a sample. In the case of $\mathrm{nZVI}$, most published studies rely on one single method; primarily using transmission electron microscopy (TEM) $[14,38,39]$ or a combination of TEM with one other size-measurement technique $[21,40-44]$. However, many recent studies have emphasised the importance of using a multi-method approach when characterising nanoparticles to ensure the accuracy of the characterisation data $[45,46]$. Analytical methods suitable for providing particle size data are presented and discussed below, together with some nZVI demonstration data. 


\subsection{Microscopy techniques}

Microscopy techniques provide some of the most direct methods for MNP characterisation; enabling the determination of fundamental parameters such as size, shape and aggregation state by direct visualisation. Traditional optical microscopes do not offer adequate spatial resolution: they are diffraction limited (for visible light $d \approx \lambda / 2 \approx 250 \mathrm{~nm}$ ), so electron microscopy techniques are required to examine MNPs at the single particle level. The acquired images can be post-processed to obtain a number-weighted size distribution of the MNPs that can assist in confirming the results obtained from other bulk size-measurement techniques (e.g. Dynamic Light Scattering - DLS). As microscopy methods are effectively single particle counting methods, a large number of particles need to be analysed in order to acquire statistically representative results. The required number of particles to be analysed is dependent on the distribution and the desired accuracy [47], but is typically in the several hundreds to thousands of particles $[48,49]$. This can be largely automated by the use of image processing programs such as ImageJ [50]. However, some manual intervention is often necessitated by the limited ability of programs to recognise dimers or larger aggregates, even with the use of various boundary metrics (e.g. circularity). Furthermore, appropriate sample preparation is critical in determining accurate sizes and distributions from these methods. For the characterisation of nZVI, the most commonly applied microscopy techniques are TEM $[14,38,39]$, scanning electron microscopy (SEM) [37, 51, 52] and atomic force microscopy (AFM) [53-55].

\subsubsection{Transmission electron microscopy (TEM)}

Transmission electron microscopy is a single particle characterisation technique that uses an accelerated beam of electrons to illuminate thin samples (typically $<100 \mathrm{~nm}$ ). In the commonly applied bright-field TEM, the transmitted electrons produce a 2D projection of the specimen on to an imaging device such as a charge coupled device (CCD). Due to the short de Broglie wavelength of the accelerated electrons, TEM can image particles beyond the diffraction limit of light microscopies and provide direct visual information about size, shape and aggregation state; as well as information 
about crystallinity and lattice spacing when using high resolution TEM [56-58]. This ability to directly image nanoscale materials such as nZVI is a powerful advantage over other methods of particle characterisation such as DLS or FFF, and TEM and its variants have been widely used for nanoparticle characterisation [28, 59-61]. For example, while DLS can be used to derive the hydrodynamic diameter of particles (see Section 2.2.1), this technique requires an inherent assumption that the diffusing "particles" are spherical, which may not necessarily be the case. TEM can offer irrefutable evidence of the nZVI core shape and aspect ratio that can assist in the appropriate interpretation of complementary data. It is also important to note that TEM measures the hard particle limits defined by the iron components (in the case of $\mathrm{nZVI}$ ), rather than the hydrodynamic diameter which extends to include the adsorbed organic stabilisers with low TEM contrast. On the other hand, inorganic surface layers can also be examined, and this may be very useful in examining core-shell structures of $n Z V I$ such as oxide minerals $[35,38,62]$ (Figure 2 ), or palladium used for enhancing $n Z V I$ environmental stability or catalytic reactivity [63].

\section{Figure 2}

Other modes of TEM can be used to provide additional physicochemical information about the samples. For example, dark-field imaging, which produces contrast by electron density differences, may reveal the individual particles within nZVI agglomerates linked by oxide layers $[63,64]$, and even internal grain structures [59]. X-ray energy dispersive spectroscopy (XEDS) can provide further details, such as semi-quantitative information about the elemental composition of a collection of nZVI particles, and can be used to map single particles with scanning TEM (STEM) - XEDS (Figure 3), which may be valuable in assessing the spatial distribution of bimetallic nZVI dopants, or the mechanisms of reactions and effectiveness of remediation at the nanoscopic level $[38,61,63,65]$. One of the advantages of TEM-XEDS is that the thin specimens lead to greater spatial resolution than that achieved with SEM-XEDS, as the large sub-surface interaction volume can limit the SEM-XEDS resolution at high voltages (see Section 2.1.2). 


\section{Figure 3}

Sample preparation is one of the challenging aspects of TEM analysis. For the determination of particle size distributions using TEM, the specimen needs to be thin (typically $<100 \mathrm{~nm}$ ) and should ideally consist of well separated monolayers of particles in a uniform focal plane. The microscopes operate under high vacuum and the samples must be dried prior to analysis. This presents a challenge due to the high reactivity of nZVI with oxygen under normal atmospheric conditions and the magnetic properties of nZVI also complicate matters. Furthermore, slow drying processes can induce aggregation or agglomeration as a result of the increase in absolute particle concentrations and increased ionic strength. Sample preparation techniques are thus ideally fast (e.g. flash drying) and should avoid contact with oxygen rich atmospheres by the use of anaerobic chambers or vacuum desiccators. One approach may be to immobilise nanoparticles on to carbon coated grids with a functionalised polymer (e.g. poly-L-lysine - see later example for SEM, Figure 4 e), from which excess sample can be removed prior to drying, and the immobilised fraction bound to the surface can be dried without the risk of inducing aggregation. There is also need for caution to minimise damage to the samples from the high energy electrons, which may for example, contrary to expectation, induce oxidation of the outer layers of $\mathrm{nZVI}[57,66]$. Therefore, it is recommended that acquisition parameters be optimised in regions that are close to, but not directly aligned with, the actual regions of interest. Finally, once prepared, samples should be stored appropriately in a dry, inert environment (e.g. a vacuum desiccator) and analysed within a short timeframe to minimise transformation artefacts [67].

\subsubsection{Scanning electron microscopy (SEM)}

Scanning electron microscopy (SEM) is a technique whereby finely focused electron beams are raster scanned to image the surface of samples. Rather than imaging the transmitted electrons as in TEM, SEM utilises electrons that are generated when the beam interacts with the sample surface. Thus, it is a surface sensitive imaging technique. Three phenomena are routinely used in different modes of 
analysis: secondary electron (SE) mode, backscattered electron (BSE) mode, and XEDS mode (as in TEM).

SEM have been used to examine the aggregation state, surface morphology $[53,68,69]$ (see also Figure 4), and spatial distribution of nZVI on solid substrates [69-72], and, less frequently, for size determination. While SEM is generally more accessible than TEM (i.e. more common in research laboratories), spatial resolution is poorer in SEM than in TEM, even for SEMs with a field-emission source (FEG-SEM). This is dependent on several factors such as the acceleration voltage of the beam, working distance and the atomic number and density of the material. While the best SEMs can achieve sub-nanometre resolution in SE/BSE modes and resolve sub-100 nm MNPs in X-ray imaging modes, in practice, accurate size determination with commonly available microscopes using SE mode is limited to $c a .10 \mathrm{~nm}$ and slightly worse for BSE mode. SEM-XEDS images have even higher limits for accurate sizing due to the large sub-surface interaction volume, which is highly dependent on the beam energy and sample density (Figure 5). Typically, a beam energy approximately twice that of the desired X-ray emission line is used. For Fe L-edge emission (6.4 keV) this is $12.8 \mathrm{keV}$, and a beam of this energy at a spot size of $1 \mathrm{~nm}$ would provide a lateral resolution of $c a .0 .5 \mu \mathrm{m}$. Besides, unlike TEM, SEM cannot accurately determine the oxide layer thickness in nZVI, unless for example, the particles have a thick oxide layer, such as that more commonly found on ZVI microparticles. In such cases, comparing the BE and BSE images may reveal regions of different electron density (Figure 4c), or XEDS may be acquired for qualitative element/composition identification.

\section{Figure 4}

Figure 5

Sample preparation for SEM is comparatively easier than for TEM because the specimens do not need to be so thin. However, as with TEM, care is still required in minimising exposure to air, while ensuring that the samples are dry. Furthermore, they need to be electrically conductive: nonconductive samples require surface coating via sputtering or evaporative processes to impart surface conductivity and this may be necessary for samples with high organic stabiliser content. 


\subsubsection{Scanning probe microscopy (SPM)}

Scanning probe microscopy (SPM) is a technique that utilises a sharp tip (i.e. probe) to scan over the surface of a sample. There are many types of SPM available including for example, atomic force microscopy (AFM), scanning tunnelling microscopy (STM) and scanning near-field optical microscopy (SNOM or NSOM); however, the application of SPM to $\mathrm{nZVI}$ in the literature is limited. AFM is capable of providing quantitative information about the particle height ( $\approx$ size, if spherical) and morphology of nZVI $[73,74]$, and its aggregation state or distribution over a flat surface. Unlike conventional TEM and SEM, AFM can be conducted under a wider range of conditions (e.g. in vacuum, liquid or moist conditions, or in other controlled environments), and as it does not involve the use of high energy electron beams, it could be advantageous in the case of nZVI characterisation with respect to minimising sample damage and oxidation. For conductive samples, STM can be used to image the topography at atomic resolution by exploiting the tunnelling current generated between an electrically biased sharp tip and the sample surface. It has been applied to study the change in surface profiles after reaction with $\mathrm{Cr}$ (III) and $\mathrm{Se}(\mathrm{IV})$, where they found that roughness (protrusions) on the surface had smoothed out as a result of the reaction [75].

However, most of these techniques are less commonly employed as they tend to be more specialised and therefore are often not available in many laboratories.

\subsubsection{Other microscopy methods with potential applications}

Several novel method developments have recently been made with potential applications in nanomaterials analysis. For example, hyperspectral dark-field imaging with the aid of multivariate classification algorithms [76] were able to provide information on the size, aggregation state, and composition of $\mathrm{Ag}, \mathrm{CeO}_{2}$ and $\mathrm{TiO}_{2}$ nanoparticles when these were analysed in representative environmental media. This technique may potentially enable the examination of iron-based nanoparticles in environmental waters, although there may be difficulties arising from the presence of naturally occurring colloids which may also contain iron. Furthermore, light microscopy has been 
revolutionalised in the last decade with the advent of super-resolution microscopy (SRM) that offers spatial resolution surpassing the classical diffraction limit [77-79]. While most of these require fluorescence labelling that may not be compatible with nZVI, method such as scanning near-field optical microscopy (SNOM) that do not require labelling may have potential in nZVI imaging. Finally, helium ion microscopy (HeIM or SHOM), is also an imaging technique that is becoming accessible, where $\mathrm{He}$ ions are used as the probe instead of electrons [80]. This results in improved surface sensitivity (reduced interaction volume), better spatial resolution (shorter de Broglie $\lambda$ ) and larger depth of field (lower beam divergence), and has been used to examine the surface deposition morphologies of nanocluster deposits [81].

\subsection{Light scattering techniques}

Light scattering techniques are commonly used to determine the size and aggregation behaviour of nanoparticles in suspensions [82]. The light source can be laser light, X-rays or neutrons and the choice of the light source will depend on the size range and particle compositions of the sample to be analysed [32]. Nowadays, dynamic light scattering (DLS) is the most commonly utilised techniques for sizing nanoparticles [83] as it offers several advantages, such as rapid analysis, simple operations and minimum perturbation of the samples [84]. Other commonly used light scattering techniques for the characterisation of MNPs include small angle X-ray scattering (SAXS) which enables the characterisation of both monodispersed and polydispersed samples, laser-induced breakdown detection (LIBD), which is able to detect trace amount of NPs in aqueous suspensions, and static light scattering (SLS), also called multi angle (laser) light scattering (MALS or MALLS) which can provide valuable information on particle shape factors when combined with DLS [32]. To date, few studies have reported the use of light scattering techniques to measure the size and aggregation behaviour of nZVI $[21,22,26,40,43,85-90]$. This is largely due to inherent analytical challenges. The detailed discussion about light scattering techniques below is limited to DLS, since this is the only light scattering technique used for characterising nZVI. 


\subsubsection{Characterisation of nZVI using dynamic light scattering}

Table 1 summarises results from all of the studies which have used DLS to characterise nZVI and places particular focus on the reported methods of sample preparation and data processing.

DLS measures the diffusion coefficient of particles by correlating the fluctuations of the scattered light intensity (i.e. coming from the Brownian motion of the particles and from the fact that neighbouring particles can have constructive or destructive interference on the scattered light intensity in a certain direction) over time [32]. The Z-average hydrodynamic diameter can then be calculated by applying the Stokes-Einstein equation. Detailed information on this method, including physical principles, mathematical models, and limitations can be found elsewhere [91]. The limitations of this technique mainly relate to the analysis and interpretation of the data obtained, especially for polydispersed samples [91]. DLS is known to be very sensitive to larger particles and a very small number of large particles sedimenting during the analysis (e.g. due to aggregation processes) can induce biased results [46]. This is mostly due to the strong particle size dependence of the scattering intensity. In fact, according to the Rayleigh approximation, the intensity of light scattered by a particle is proportional to the sixth power of its diameter. This causes large particles to scatter far more light than small particles [92]. Therefore Z-average or intensity values tend to overweight the contribution of larger particles/aggregates [46]. In addition, for multimodal size distributions, the conversion of the autocorrelation function to a diffusion coefficient poses a major mathematical problem (i.e. small variations can give large deviations in the output). For this reason but also due to the fact that the signal from larger particles dominates over smaller ones, a common rule is that DLS cannot be applied to samples with polydispersity indices above $\sim 1.5-1.7$ [32]. However, in most studies, there is no information regarding the polydispersity index (PDI) of sample; information that can be extracted from the analysis of DLS results and which can be very useful to determine the best dispersion strategies to adopt for a specific sample. 
Previous studies using nZVI have demonstrated that this class of nanoparticle has a great tendency to aggregate, especially when particles are not surface stabilised (i.e. coated). This often results in samples having high polydispersity with the presence of substantially large aggregates [19-22, 36, 93]. In order to obtain more accurate and reliable data with DLS, the polydispersity of the sample can be reduced by using different sample preparation methods and data processing. Sample preparation methods are documented in Table 1. The most simple and applied sample preparation method to break down nanoparticle aggregates (i.e. aggregates formed during storage) is sonication $[22,26,40,85,86,88]$. Different sonication times may be used depending on the aggregation state of the sample prior to measurement. Honetschlägerová et al. [85] applied different sonication times and found that above 15 minutes, no further change was observed. Saleh et al. [22] combined sonication with an ultrasonic probe for 30 minutes and rotator mixing for 72 hours and obtained fairly stable samples. However, based on the studies presented in Table 1, it is very difficult to reach a conclusion on the effect of sonication time since there are too many parameters which differ among these studies. In fact, in some cases, sonication is not the only employed sample preparation method (e.g. in some studies, samples are diluted prior to measurement) and thus it is difficult to evaluate which of the applied method has the most impact on sample stabilisation. Moreover, these studies have used different particle concentration (i.e. from as low as $5 \mathrm{mg} \mathrm{L}^{-1}$ to $2.5 \mathrm{~g} \mathrm{~L}^{-1}$ ), different surface coatings (i.e. bare nZVI, polymer or surfactant stabilised nZVI) and different chemical conditions (i.e. different $\mathrm{pH}$ and ionic strength), which are all known to influence particle aggregation. This suggests that, for DLS in particular, standard sample preparation protocols need to be developed with the prospect to combine data from heterogeneous sources into integrated and harmonized databases.

The particle concentration of the sample is also important and this may need to be adjusted by dilution. In fact, for charged particles, the electrostatic forces arising between particles can have an effect on their diffusive behaviour and this effect is concentration dependant, with a maximum occurring at a point called "gel-formation" [32]. Phenrat et al. [26] tested different nanoparticle 
concentrations and found that aggregation rate increased with increasing particle concentration. This issue can generally be overcome by diluting the sample (e.g. with MQ water) but this will affect the aggregation state of the sample. It is quite clear though that due to the limitations of DLS, this technique cannot be successfully used to assess primary particle size in commercial nZVI concentrated products as they are generally too concentrated. Hence, if the purpose of the analysis is to measure the aggregation behaviour of the sample, then it is more relevant to report the diffusion coefficient rather than the size, without diluting the sample.

As aggregation of charged particles is also $\mathrm{pH}$-dependant with maximum aggregation occurring at the point of zero charge (PZC) (i.e. around pH 8 for nZVI [28]), reducing or increasing the $\mathrm{pH}$ far away from the PZC could be one way to form stable dispersions. Kim et al. [88] investigated the aggregation behaviour of two polymer-coated nZVI materials at two different $\mathrm{pH}$ values $\mathrm{pH} 6$ and $\mathrm{pH} \mathrm{8)} \mathrm{and} \mathrm{found} \mathrm{that} \mathrm{aggregation} \mathrm{increased} \mathrm{with} \mathrm{decreasing} \mathrm{pH}$.

Pre-fractionation of the sample can also be used to obtain more accurate characterisation. Phenrat et al. [86] prepared three different intrinsic particle size distributions by sequential, gentle sedimentation. They found a bimodal size distribution for unfractionated samples while samples collected in the supernatant showed a monomodal size distribution with smaller particle size. Another way to reduce the polydispersity of the sample which has not yet been tested for $\mathrm{nZVI}$ is to couple DLS with a size fractionation technique such as Flow Field-Flow Fractionation (FIFFF). In this way, more complex characterisation of size fractions can be potentially achieved [94]. To date, only one study has been reported on the use of this combination for the characterisation of $\mathrm{C} 60$ nanoparticles [95].

As discussed previously, the data derived from DLS measurements are intensity-based distributions or averages which tend to overweight the contribution of larger aggregates and hence overestimate particle size [46]. Nowadays, mathematical conversion to volume or number distributions are quite 
often used as they can correct for overestimation to some extent [96]. However, these conversions should be made only with good knowledge of the particle shapes, polydispersity and relevance of other key assumptions [97].

It can be clearly seen from the above discussion that many dispersion strategies have been employed and tested in an attempt to reduce the polydispersity of the studied samples. Results from Table 1 shows that different dispersion strategies resulted in different findings in terms of size and sample polydispersity (i.e. monomodal or bimodal size distribution). Because of the various conditions used in these studies (i.e. different synthesis method, different particle concentration, different surface coating, different dispersion media), it is very difficult to draw conclusion on the accuracy of the results and more importantly to compare the results from different studies. Therefore, a general effort should be made to develop standardised procedures for sample preparation and dispersion in order to obtain nanoparticle characteristics (e.g. size and dispersion) that can be easily comparable. Furthermore, the development and synthesis of standard ZVI nanoparticles from commercial laboratories for the purpose of instrument calibration and validation of developed analytical methods should be the focus of future research.

\section{Table 1}

\section{Bulk composition and surface chemistry analysis}

Bulk composition and surface chemistry are also important characteristics that need to be rigorously determined in any nZVI materials during experimentation and before they are deployed into the environment. In fact, the metallic iron content as well as the composition of the oxide shell at the time of delivery will have a substantial impact on the nZVI performance $[98,99]$.

Among different analytical techniques which have been applied to determine these properties, X-ray diffraction (XRD) [28, 31, 35, 52, 53, 100-107], X-ray adsorption spectroscopy (XAS) [28, 35, 64, 100, 107-109] and X-ray photoelectron spectroscopy (XPS) [16, 28, 31, 35, 70, 101, 102, 104, 106-108, 110-112] are the most common $\mathrm{X}$-ray techniques used to characterise $\mathrm{nZVI}$. 


\subsection{X-ray diffraction (XRD)}

X-ray diffraction (XRD) is a simple, versatile, non-destructive and comparatively inexpensive technique for identifying the phases of crystalline materials. Broad applications include assessment of percentage crystallinity; identification of fine-grained minerals such as nanoparticles, nano-clays and mixed layer clays that are difficult to distinguish optically; determination of unit cell dimensions; and evaluation of sample purity. If the sample is finely ground and homogenised; the bulk compositional chemistry of the material can be obtained through XRD $[35,100,103,106,113,114]$.

The principle of XRD is based on Bragg's Law $(n \lambda=2 d \operatorname{Sin} \theta$; where $\lambda$ is the wavelength of the X-rays, $\mathrm{n}$ is the order of diffraction, $d$ is the spacing between consecutive parallel planes of a crystal and $\theta$ is the complement of the angle of X-ray incidence) in which monochromatic X-rays constructively interfere with a crystalline sample and produce diffracted X-rays. More detailed information on this method can be found elsewhere $[115,116]$

Table 2 provides a summary of the different studies which used XRD for nZVI characterisation. nZVI samples often provide very broad XRD peaks due to the short range order structure (i.e. amorphous nature) of the iron nano-phases, including the $\mathrm{Fe}(0)$ phase $[53,113,117]$. However, a recent study has found that ultrasound assisted synthesis can provide more crystallinity to $\mathrm{Fe}(0)$ [118]. Peak broadening generally occurs due to surfactant artefacts in surfactant stabilised nZVI samples [37, $119]$, sample ageing [120] or reactions with contaminants [53, 68, 121-125]. Some polymers (e.g., polyacrylic acid, polyvinylpyrrolidone) stabilised nZVI samples may show no XRD peak of iron phases due to the combination of amorphous and non-crystalline phases and surfactant artefacts [119]. Previous studies focusing on the green synthesis of nZVI also found samples produced with green methods show no XRD peaks, especially the characteristic peak of zero-valent iron ( $\alpha$-Fe) (i.e. $44.9^{\circ}$ $2 \theta$ ) indicating that the green $\mathrm{nZVI}$ are amorphous in nature [126-128]. These results suggested that XRD may not be suitable for all nZVI products, especially those coated with organic polymers or produced with green synthesis methods, which is one of the limitations of this approach. 
For determining the crystal structure and quantifying the different phases, additional advanced numerical technique such as Rietveld refinement is often required. However, quantification by XRD is usually not reported because of the uncertainties related with the presence of amorphous and nano-crystalline materials and this technique is generally employed only for identification of major crystalline phases. This method can also be applied to indirectly analyse the composition of major elements (constituting the crystalline phases); however, the sensitivity is much lower than with other elemental analytical techniques such as inductively coupled plasma mass spectrometry (ICPMS). The detection limit of an individual phase present in a mixed material is about $2-3 \%$ and this quantification is limited to well crystalline phases. In most previous studies where XRD was used as an nZVI characterisation tool, the researchers were confined only to identification of iron phases and evaluation of crystallinity (Table 2). Iron phases in nZVI samples identified by XRD patterns include $\mathrm{Fe}^{0}$, ferrihydrite, magnetite $\left(\mathrm{Fe}_{3} \mathrm{O}_{4}\right) /$ maghemite $\left(\gamma-\mathrm{Fe}_{3} \mathrm{O}_{4}\right)$, lepidocrocite $(\gamma-\mathrm{FeOOH})$ and wuestite (FeO) (Table 2). The presence of $\mathrm{Fe}^{0}$ and oxides and/or hydroxides of iron support the core-shell structure model of nZVI [64]. The extent of oxides/hydroxides present in an nZVI sample depend on its synthesis and storing conditions, duration of ageing, presence of other chemical elements/compounds, etc. (Table 2).

Valuable information about the particle size of a material might be derived from XRD patterns of crystallites less than about $100 \mathrm{~nm}$ in size. These nano crystallites provide appreciable broadening (FWHM - Full Width at Half Maxima) of the XRD peaks. By entering a corrected peak broadening value (corrected for instrumental contribution and crystal strain; $\beta$ ) in Scherrer's equation $(D=0.9$ $\lambda / \beta \cos \theta)$ the average particle size can be estimated. The size can be estimated from a single diffraction peak if particle stress is absent, but several diffraction peaks should be involved if stress is present. However, most published studies using XRD for nZVI characterisation have not used this method for nZVI particle size determination (Table 2), probably because of the ambiguity in the reasons for peak broadening. Rather TEM, SEM or DLS is more commonly used for this purpose (see Sections 2.1.1., 2.1.2. and 2.2.1.). 
Sample oxidation of $\mathrm{nZVI}$ can also occur during the XRD run time since a good quality pattern takes about 40 minutes to obtain when scanning in the range $10^{\circ}$ to $90^{\circ} 2 \theta$ with a step size of $0.013^{\circ}$ and around 100 sec per step. Even short exposures to air of one minute or less can significantly affect the speciation of nZVI [129], therefore an appropriate covering technique should be employed during sample preparation in order to prevent the oxidation of nZVI during the test period. Also, samples need to be prepared and stored under anaerobic conditions or an inert atmosphere prior to XRD analysis.

\section{Table 2}

\subsection{X-ray photoelectron spectroscopy (XPS)}

X-ray photoelectron spectroscopy (XPS) is an ultra-high vacuum, surface sensitive technique in which a sample is irradiated with X-rays of known energy and the kinetic energies of emitted photoelectrons and Auger electrons are measured. Elements present are identified by the characteristic binding energies, of their atomic orbitals, and determined from Equation 1:

$h v=B E+K E+\phi$

where $\mathrm{h} v$ is the incident $\mathrm{X}$-ray energy, $\mathrm{BE}$ is the photoelectron binding energy, $\mathrm{KE}$ the measured kinetic energy of the emitted photoelectron and $\phi$ is an instrumental work function (energy loss). Typical X-ray source energies are $<2000 \mathrm{eV}$ (K $\alpha$ line), with the commonest anodes being Mg (1253.6 $\mathrm{eV}$ ) and $\mathrm{Al}(1486.6 \mathrm{eV})$, with monochromatic Al K $\alpha$ sources fitted to high (spectral) resolution instruments.

Useful for a wide range of materials and sample types [31, 130], XPS provides elemental concentration and, for many elements, chemical environment and/or oxidation state information in the top-most few nanometres of surfaces, whether organic [131] or mineral with inorganic [132] or organic adsorbates [133]. Surface concentrations of elements, relative to the bulk concentrations, can give valuable indicators of specific absorption of solution-borne species, while oxidation state 
may suggest potential impacts of redox changes, re-mobilisation and bioavailability. In the context of fine particles, the last is extremely important when examining toxicity (e.g. [134]). For particles such as ZVI, XPS can monitor surface composition and chemistry as a function of time and environmental exposure $[31,130,135]$ (Table 3). Through the use of ion etching of surfaces and/or examination of photoelectron escape depths, information about the thickness of particle coatings, contamination or reaction layers may be gleaned [31, 129, 130, 136, 137] (Table 3).

Being an extremely surface sensitive technique, XPS does not provide information on the bulk chemistry of nZVI particles. Also, for the same reason, it is absolutely imperative that nZVI materials are maintained under anaerobic condition at all times during sample preparation and transfer into the instrument as even a brief exposure to oxygen can cause oxidation of the $\mathrm{nZVI}$ surface which is probed by XPS. This is often problematic or impractical unless the XPS loading port can be connected to an anaerobic chamber.

\subsection{X-ray adsorption spectroscopy (XAS)}

X-ray adsorption spectroscopy (XAS) uses synchrotron radiation to obtain information about the oxidation state, identity of nearest neighbours, bond length, coordination number and electronic configuration of an element of interest in virtually any sample (see [138] for review). Using this technique the valence and chemical state of Fe on both the particle surface and in the bulk volume can be determined $[28,35,106,108]$ (Table 3$)$.

One of the most important advantages of this technique is the possibility of speciation analysis in any sample under almost any environmental condition (without the need of separating the element of interest through an extraction procedure) $[139,140]$. This is a particular advantage in the case of $\mathrm{nZVI}$ as samples can be analysed as slurries (or frozen) or as dry powders as long as they are mounted in a way that prevents their contact with oxygen. This is easily achievable by sandwiching 
the sample between two layers of a material such as polyimide, which is virtually transparent to the X-rays of interest.

On the other hand, the interpretation of XANES/EXAFS spectra can be very intricate and timeconsuming in samples with complex mixture of chemical species, because the spectra obtained represent the weighted sum of all the species in the analysed volume [141]. Consequently, the quantification of a very thin layer of oxidised Fe on the surface of nZVI particles, which is easily detected by XPS, would be difficult to quantify by XAS unless it represented at least a few $\%$ of the total Fe.

Table 3

\section{Characterisation of commercial products}

To demonstrate some of the advantages and limitations of the major techniques described above we used them to characterise a number of commercial ZVI/nZVI products. Five different commercial products with different physicochemical properties, including three powders and two slurries, were examined. Major physical and chemical properties of the materials reported according to the manufacturers' specifications are shown in Table 4.

\section{Table 4}

All sample preparation steps for the following analyses were conducted under anaerobic conditions, and anaerobic conditions were also maintained during analysis as detailed below.

DLS analysis was attempted using a Nicomp 280 instrument. In order to improve the dispersion of the particles the samples were diluted up to 100 times in degassed milli-Q water and sonicated for 10-75 minutes. The samples were transferred under anaerobic conditions to cuvettes that were subsequently sealed to prevent oxidation during analysis. Despite the dilution and sonication steps, sedimentation of particles was visible in all samples during the analysis period. This may have been prevented by combining different sample preparation methods in addition to dilution and sonication. For instance, pre-fractionation of the sample to remove the larger aggregates has already 
proved to be an efficient method to reduce the sample polydispersity [86, 142]. However, this method would have been ineffective if the sedimentation of particles was caused by the non-surface stabilisation of the manufactured $\mathrm{nZVI}$, the $\mathrm{pH}$ and ionic strength of the solution which are both known to favour the aggregation (or disaggregation) of nanoparticles or the oxidation of the ZVI nanoparticles which can cause the formation of large corrosion products (even though the samples were not in contact with air during sample preparation and analysis). Since DLS measurements are based on the Brownian motion of the particles, evidence of sedimentation indicated that this widely used characterisation technique would not produce reliable or reproducible results for these materials. This stresses the need to develop standard sample preparation protocols for this instrument which would help in the acquisition of reliable, accurate and comparable data among the scientific community. These protocols should include essential parameters such as final particle concentration, solution chemistry (i.e. $\mathrm{pH}$, ionic strength) or the use of surface stabilisers to achieve the adequate sample polydispersity for DLS analysis.

In order to further investigate the dispersion and morphology of the five commercial products, the samples were then examined by SEM (FEI Quanta 450 FEG-ESEM operated at $20 \mathrm{kV}$ ). All samples were prepared using ethanol to prevent the oxidation of $\mathrm{nZVI/ZVI}$ products during sample preparation. Figure 6 shows SEM images of 2 commercialised ZVI products (i.e. one powder and one slurry). It is clear from these images that both samples are highly polydispersed (i.e. from nanoscale particles to micron scale aggregates) and the aggregates from the slurry sample (Figure 6b) exhibit an open, porous morphology suggesting that these aggregates were formed under unfavourable conditions (i.e. the total interaction energy between particles is positive which resulted in high attachment efficiency).

\section{Figure 6}

XRD analysis was conducted in order to assess the relative proportion of ZVI in the materials and the identity of any other major Fe species or Fe corrosion products. The XRD patterns were obtained, 
using a PANalytical Empyrean X-ray diffractometer by capping the samples (prepared under anaerobic conditions) with polyimide film in order to prevent oxidation during the analysis (Figure 7). The thickness of the polyimide film used was $8 \mu \mathrm{m}$, (note that thicker, $1 \mathrm{~mm}$, polyimide film obscured the diffraction region of the sample at $2 \theta$ values $\left.10-30^{\circ}\right)$.

\section{Figure 7}

The XRD quantification results indicated a significant disparity in the contents of ZVI and iron oxidehydroxide in the measured samples as compared to the values reported in the manufacturers' specifications (Table 5). The oxide and hydroxide phases of iron in the samples included magnetite $\left(\mathrm{Fe}_{3} \mathrm{O}_{4}\right)$ and/or maghemite $\left(\gamma-\mathrm{Fe}_{2} \mathrm{O}_{3}\right)$, lepidocrocite $(\gamma-\mathrm{FeOOH})$ and wüstite $(\mathrm{FeO})$ (Figure 7) $[53,143]$. Zero-valent iron is characterised by peaks appearing at $2 \theta$ values of $44-45^{\circ} ; 65-66^{\circ}$ and $82-85^{\circ}[14$, $15,28,39,100,101,103,113$ ]. We note that the ZVI contents in some samples (P2 \& P3) were remarkably less than that specified in the manufacturers' reports. This may be partly due to the difficulty to quantify XRD data for $\mathrm{nZVI}$ as reported above or to oxidation of ZVI particles occurring during storage and transportation. Therefore, alternative method to polyimide film should be tested to find the best suitable method to prevent nZVI oxidation prior and during XRD analysis.

\section{Table 5}

Figure 8 shows the Fe $2 p$ photoelectron emission spectra (Kratos - AXIS Ultra) of the five commercially-available ZVI particles obtained for this study. Once again, we note that these materials were prepared in an anaerobic chamber and an anaerobic transfer chamber was used to transfer the materials into the XPS instrument, thus preventing oxidation of the products prior to measurement. As can be seen, metallic $\mathrm{Fe}, \mathrm{Fe}(0)$, was only present in the surface layers of samples S1 and S2. No Fe(0) was evident on the surfaces of the other three products. The majority of intensity contributions, however, derive from $\mathrm{Fe}(\mathrm{II})$ and $\mathrm{Fe}(\mathrm{III})$ associated with oxygen on all sample surfaces $[28,31,108,113,144,145]$, with P1, P2 \& P3 all apparently identical in Fe oxidation product exposure. 


\section{Figure 8}

XAS studies were conducted in quick-scan transmission mode at the Materials Research

Collaborative Access Team (MRCAT) beamline 10-ID, Sector 10, at the Advanced Photon Source of the Argonne National Laboratory, U.S.A. The storage ring operated at $7 \mathrm{GeV}$ in top-up mode. Calibration was performed by assigning the first derivative inflection point of the absorption K-edge of Fe metal (7112 eV), and each sample scan was collected simultaneously with an Fe metal foil. The collected spectra were analysed using the Athena software program in the computer package IFEFFIT [146] for data reduction and WinXAS 3.0 [147] for data fitting. The data were converted from energy to photoelectron momentum (k-space) and weighted by k3 using WinXAS. Linear combination fitting (LCF) was performed on the data using a dataset of reference spectra including metallic Fe as well as a number of iron oxy/hydroxides minerals. Furthermore, extended X-ray absorption fine structure (XANES) spectra were calculated over a typical k-space range with a Bessel window. Fourier transforms were performed to obtain the radial distribution function in R-space. Plotted R-space $(\AA)$ data are not phase shift corrected. The results of the LCF procedure (Table 6, Figure 9) indicated that most of the Fe was present in metallic form in samples P1, S1 and S2; with the remaining Fe in these samples present as magnetite and maghemite. In samples P2 and P3 most of the Fe was oxidised, with maghemite, magnetite and wuestite dominating the Fe speciation. The lower Fe(0) content as assessed by XAS in comparison to XRD (Table 4 and 5) are most likely due to differences between these two techniques. XRD relies on the crystallinity of the phases investigated (i.e. long-range structure) while XAS probes directly the core structure of the Fe atoms and it is therefore less dependent on crystallinity. It is likely that the corrosion layer present on the nZVI materials has a much lower crystallinity than the $\mathrm{Fe}(0)$ core. As a result the proportion of Fe(0) could be overestimated by XRD. As sample P2 has a larger size, the underestimation of the corrosion shell by XRD is expected to be lower in that case.

Table 6

Figure 9 
Figure 10 shows the Fourier transformed radial distribution functions (RDFs) of the five samples and an iron metal foil. The fit data (Table 7) shows the coordination parameters of Fe in the samples. Metallic Fe is present in each sample and results of the Fe metal foil show the basic parameters

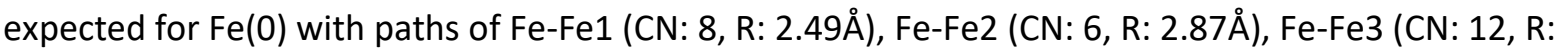

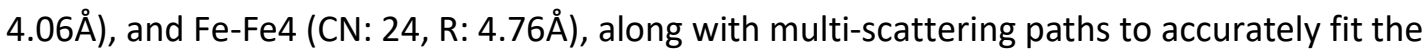
spectrum. The fitting of the Fe metal foil involved fixing the $\mathrm{CN}$ of each path determined by $a b$ initio calculations by FEFF8 and allowing atomic distance to float, resulting in R values close to theoretical

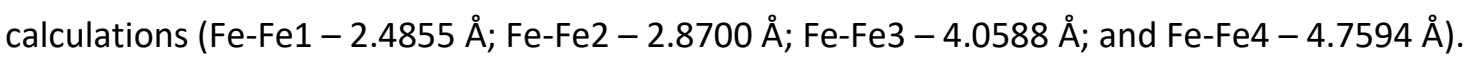
Despite LCF results indicating minor portions of Fe-III (oxy)hydroxides in samples P1, S1, and S2, the EXAFS fitting was unable to accurately fit components for Fe-III (oxy)hydroxides. The transformed RDFs represent the average of all signals in a given sample, which may inhibit identification of some low quantity phases. The results for samples $\mathrm{P} 1, \mathrm{~S} 1$, and $\mathrm{S} 2$ indicate the presence of $\mathrm{Fe}(0)$ as the primary phase with $\mathrm{CN}$ and $\mathrm{R}$ values representative of the Fe metal foil and $a b$ initio data noted above. Samples P2 and P3 added complexity to the fitting process with the presence of oxidized iron minerals. The LCF results of P2 indicate the presence of Fe(III) oxide minerals and Fe(0). The components of $\mathrm{Fe}(0)$ metal in $\mathrm{P} 2$ (Fe-Fe1; $\mathrm{Fe}-\mathrm{Fe} 2 ; \mathrm{Fe}-\mathrm{Fe} 3$; and $\mathrm{Fe}-\mathrm{Fe} 4)$ align well with parameters of the iron metal foil results. The Fe(III) mineral components of P2 yield an Fe-III-O path with $\mathrm{CN}$ of 6 at $1.94 \AA$ and an Fe-Fe2 Oxide path with CN of 6 at $2.94 \AA$ (Table 7). These fit parameters for the Fe(III) mineral components in P2 align well with ab initio calculation for LCF determined minerals of magnetite (FellI-O - CN: 6, R: $2.00 \AA ̊$; Fe-Fe2 Oxide - CN: 6, R: $2.89 \AA$ ), maghemite (Fe-III-O - CN: 6, R: 2.08 ̊̊; Fe-Fe2 Oxide - CN: 6, R: $2.94 \AA$ A), and lepidocrocite (Fe-III-O - CN: 6, R: $1.99 \AA ̊$; Fe-Fe2 Oxide CN: 6, R: $3.04 \AA$ Å). The LCF results for P3 indicate the presence of wuestite (Fe-II-O) in addition to $\mathrm{Fe}(\mathrm{III})$ oxide minerals and Fe(0). EXAFS fitting results (Table 7) for P3 demonstrate an additional path of Fe-II-O with a CN of 6 at $2.19 \AA$ relative to P2, which supports the presence of wuestite (Fe-II-O CN: 6, R: $2.15 \AA$ ). However, the Fe-Fe2 Oxide R value is larger than the $3.24 \AA$ Fe-Fe bond distance in wuestite and larger than the average second shell Fe-Fe distance of the oxidize Fe minerals 
determined by LCF for P3 (magnetite, maghemite, and wuestite). Overall, the EXAFS fitting results (Table 7) support the LCF information (Table 6) as well as visual evidence in Figure 10 where P1, S1, and S2 possess similar RDFs to the Fe metal foil. The Fe metal foil peaks are observable in P2 in addition to peaks associated with Fe-III (oxy)hydroxides. For P3, the Fe metal foil peaks are less obvious and the presence of wuestite yields an RDF that is different than that of the other four samples.

\section{Figure 10}

Table 7

These results indicate that in all cases the content of $\mathrm{Fe}(0)$ present in the materials was less than that reported by the manufacturers. However, in three cases (P1, S1 and S2) both XRD and XAS analysis showed that metallic Fe comprised the large majority of the materials with the rest composed of magnetite, maghemite and lepidocrocite. In the case of the S1 and S2 materials, XPS analysis showed that $\mathrm{Fe}(0)$ was present on the surface of the particles, while in the case of P1 the lack of a peak indicative of $\mathrm{Fe}(0)$ indicates that a continuous shell of oxidised Fe was present. In the case of $\mathrm{P} 2$ and $\mathrm{P} 3$, all techniques showed that oxidised forms of Fe were dominant both on the surface and in the core of the particles. This characterisation study clearly demonstrates the complementarity of the techniques employed, and shows the importance of a thorough characterisation not only for laboratory experiments but also in the context of understanding the performance and characteristics of commercial materials proposed for use in field applications.

\section{Analytical challenges for characterizing nZVI in real groundwater samples}

To date, most nZVI studies have focused on the characterisation of freshly synthesised nanomaterials in simple matrices. However, the high reactivity of nZVI particles makes them highly dynamic in complex environmental systems such as groundwater [148]. Understanding their behaviour under environmental conditions is crucial for determining their long-term environmental fate and performance once they are injected into contaminated groundwaters. Furthermore, 
because of the large quantity of $\mathrm{nZVI}$ required for injection in remediation applications, risk assessment of these materials needs to be conducted, and this requires the measurement of $\mathrm{nZVI}$ in groundwaters.

At present, the direct measurement of engineered nanoparticles (ENPs) in the environment is still limited by significant analytical challenges [149]. In fact, the different characterisation methods described in this review can provide accurate information for "as-manufactured" nanoparticles in simple matrices but they all present significant limitations when it comes to the detection and quantification of ENPs in more complex samples [30].

Various analytical techniques and experimental methods have been tested to predict the behaviour (i.e. aggregation/sedimentation/deposition, mobility and reactivity) of nZVI in groundwater. Some examples are given in Table 8Error! Reference source not found.. One simple approach consists of studying the individual or combined effects of different physical and chemical groundwater components (e.g. effect of a single electrolyte, $\mathrm{pH}$, organic matter concentration etc.) in order to understand how these different factors can affect the mobility and reactivity of nZVI (e.g. [40, 150156]). These studies have found that increasing the ionic strength of the solution will increase both particle aggregation (ref) and particle deposition onto soil grains (ref). However, in some of these studies, the tested electrolyte concentrations were much higher than the ones found in groundwater so the relevance of the data is questionable. The influence of humic acid concentration was also investigated and was found to enhance the stability of nZVI by reducing its aggregation and sedimentation (ref). In these studies, particle size was often measured by light scattering techniques (i.e. LLS or DLS); however, as discussed in section 2.2., the presence of large aggregates in the sample significantly affect the accuracy of the data. For this reason, Yin et al. (ref) only measured the particle size after 30 minutes (i.e. only the size of the particles remaining in suspension was measured). However, no information was provided on the sedimented particles (e.g. mass fraction). Tiraferri et al. (ref) and Dong and Lo (ref) coupled DLS measurements with UV-Vis 
spectrophotometer to investigate the sedimentation regime of the particles. These studies demonstrated a two-phase aggregation/sedimentation regime with rapid sedimentation of large aggregates followed by slow aggregation/sedimentation of the remaining particles in suspension. Particle deposition was analysed by atomic absorption spectroscopy (AAS) which was used to determine the concentration of iron in the effluent samples during column experiment studies (ref). SEM/EDS were also employed to confirm the attachment of nZVI onto soil grains (ref). The oxidation of nZVI over time (i.e. in different synthetic media) was also investigated since it was shown to also affect the particle aggregation. Different techniques were tested to determine the oxidation state of nZVI; which includes colorimeter (ref) and XRD coupled with TEM (ref).These studies confirmed the development of corrosion products over time when nZVI is aged in different electrolyte solutions. These data were well-correlated with particle size and particle sedimentation measurements, which demonstrates the effectiveness and the need to develop multi-methods approach for nanoparticle characterisation.

The results from these studies are generally easily reproducible and can help in gaining quantitative data but they are only valid for the limited conditions examined in the experiments and cannot necessarily be extrapolated to predict behaviour in natural systems. A more realistic approach would be to investigate the behaviour of nZVI directly in natural groundwater samples. However, further research in this area is required, partly because this type of investigation faces significant analytical challenges.

Various field-scale studies of nZVI injection have been reported in the literature [3, 20, 157-162] but due to a lack of appropriate analytical methods that can directly measure and detect nZVI on site, most field studies have relied on indirect methods to quantify nZVI transport and reactivity. For instance, both a decrease in ORP and a change in solution $\mathrm{pH}$ are widely reported upon $\mathrm{nZVI}$ injection, and this is seen as evidence of the presence of $\mathrm{nZVI}$ and its mobility. However, a recent study [163] showed that the interpretation from ORP measurements is quite complex as the 
response of ORP electrodes to $\mathrm{nZVI}$ suspensions is not linearly correlated to nZVI concentration. For instance, at low $\mathrm{nZVI}$ concentration $(<50 \mathrm{mg} / \mathrm{L})$, the measured ORP likely represents a mixed potential including the contributions from $\mathrm{nZVI}$, dissolved $\mathrm{Fe}^{2+}$ and $\mathrm{H}_{2}$. ORP changes have also been reported as an indicator of nZVI reactivity. Elliot and Zhang [3] reported a good correlation between TCE degradation and ORP reduction at the closest monitoring well from the injection point. However, this correlation was less obvious at monitoring wells located further away from the injection point, where a lag period of one to several days was observed between the ORP reduction and TCE decline. To circumvent the limitations of individual methods, Johnson et al. [162] utilised a number of complimentary techniques to ensure that nZVI transport and reactivity were adequately characterised. They developed a spectrophotometric method combining visual inspection (i.e. change in colour), UV-vis absorbance measurements and the use of a tracer to directly quantify the transport of nZVI as well as to detect any flow changes during the injection. They concluded that the use of indirect indicators such as ORP, DO or $\mathrm{pH}$ is only relevant when they are used to supplement direct characterisation methods.

Table 8 


\section{Conclusions}

A thorough understanding of $\mathrm{nZVI}$ remediation potential, transport and fate in the environment can only be achieved by ensuring that experimental results are always reported in conjunction with appropriate and detailed nZVI characterisation data. This requirement is not limited to experimental and laboratory work but extends to pilot and field scale remediation efforts. A large number of analytical techniques can be employed to interrogate the physico-chemical characteristics of these materials. To some extent the choice of the combination of techniques will depend on availability but should cover key characteristics. Taking this into consideration, DLS for sizing, SEM for morphology and ICP-MS for elemental purity are most likely available at the majority of modern laboratories. Bulk mineralogical composition and surface chemistry analysis require costly instruments that may not be readily available even though access to XRD facilities is often possible. In any case, but care must be taken to handle nZVI appropriately to prevent oxidation and sample transformation during preparation and analysis. The protocols to ensure preservation of the nZVI materials will depend on the analytical technique considered and may vary from sealing the DLS vials prior to removing the samples from an anaerobic chamber to ensuring that transfer into spectroscopic instruments occurs through the use of appropriate transfer chambers.

Another issue to consider is that while for other nanoparticles certified reference materials are available, this is not the case for nZVI. In the short term, and as a minimum, standard reference materials already available for other classes of nanoparticles (such as Au nanoparticles) should be used for quality control but ultimately the availability of $\mathrm{nZVI}$ certified reference materials is required in order to confidently compare results from different laboratories.

While the techniques listed above, especially when used in combination, can provide a thorough characterisation of $\mathrm{nZVI}$ materials, the detection, quantification and characterisation of $\mathrm{nZVI}$ and nZVI-derived materials in the environment continue to pose considerable challenges that should be the focus of future research efforts. 
As most of the existing analytical techniques are mainly applicable for to the characterisation of pristine or "as-manufactured" nanoparticles, there is a need to develop standard protocols for the characterisation of $\mathrm{nZVI}$ in different environmental media with detailed procedure on sample preparation, instrumentation, key measurement parameters as well as data analysis. This has been already implemented for other nanoparticles such as carbon nanotubes $[164,165]$. These methods will also need to be validated through interlaboratory comparisons and then adopted by the nanoscience community. This will facilitate data comparison between different laboratories. 


\section{Reference}

1. R.A. Crane and T.B. Scott, Nanoscale zero-valent iron: Future prospects for an emerging water treatment technology, J. Hazard. Mater. 211-212 (2012) 112-125.

2. C.B. Wang and W.X. Zhang, Synthesizing nanoscale iron particles for rapid and complete dechlorination of TCE and PCBs, Environ. Sci. Technol. 31 (1997) 2154-2156.

3. D.W. Elliott and W.X. Zhang, Field assessment of nanoscale bimetallic particles for groundwater treatment, Environ. Sci. Technol. 35 (2001) 4922-4926.

4. W.X. Zhang, Nanoscale iron particles for environmental remediation: An overview, J. Nanopart. Res. 5 (2003) 323-332.

5. X.Q. Li, D.G. Brown, and W.X. Zhang, Stabilization of biosolids with nanoscale zero-valent iron (nZVI), J. Nanopart. Res. 9 (2007) 233-243.

6. H. Liu, T. Chen, X. Zou, Q. Xie, C. Qing, D. Chen, and R.L. Frost, Removal of phosphorus using NZVI derived from reducing natural goethite, Chem. Eng. J. 234 (2013) 80-87.

7. Z. Wen, Y. Zhang, and C. Dai, Removal of phosphate from aqueous solution using nanoscale zerovalent iron (nZVI), Colloids Surf., A 457 (2014) 433-440.

8. W.J. Epolito, H. Yang, L.A. Bottomley, and S.G. Pavlostathis, Kinetics of zero-valent iron reductive transformation of the anthraquinone dye Reactive Blue 4, J. Hazard. Mater. 160 (2008) 594-600.

9. J. Fan, Y. Guo, J. Wang, and M. Fan, Rapid decolorization of azo dye methyl orange in aqueous solution by nanoscale zerovalent iron particles, J. Hazard. Mater. 166 (2009) 904910.

10. B. Ma, W. Yu, W.A. Jefferson, H. Liu, and J. Qu, Modification of ultrafiltration membrane with nanoscale zerovalent iron layers for humic acid fouling reduction, Water Res. 71 (2015) 140149.

11. J.G. Darab, A.B. Amonette, D.S. Burke, R.D. Orr, S.M. Ponder, B. Schrick, T.E. Mallouk, W.W. Lukens, D.L. Caulder, and D.K. Shuh, Removal of pertechnetate from simulated nuclear waste streams using supported zerovalent iron, Chem. Mater. 19 (2007) 5703-5713.

12. G. Naja, A. Halasz, S. Thiboutot, G. Ampleman, and J. Hawari, Degradation of hexahydro-1, 3, 5-trinitro-1, 3, 5-triazine (RDX) using zerovalent iron nanoparticles, Environ. Sci. Technol. 42 (2008) 4364-4370.

13. G. Kim, W. Jeong, and S. Choe, Dechlorination of atrazine using zero-valent iron ( $\mathrm{FeO}$ ) under neutral pH conditions, J. Hazard. Mater. 155 (2008) 502-506.

14. J.T. Nurmi, P.G. Tratnyek, V. Sarathy, D.R. Baer, J.E. Amonette, K. Pecher, C. Wang, J.C. Linehan, D.W. Matson, R.L. Penn, and M.D. Driessen, Characterization and properties of metallic iron nanoparticles: Spectroscopy, electrochemistry, and kinetics, Environ. Sci. Technol. 39 (2005) 1221-1230.

15. Y. Liu, H. Choi, D. Dionysiou, and G.V. Lowry, Trichloroethene hydrodechlorination in water by highly disordered monometallic nanoiron, Chem. Mater. 17 (2005) 5315-5322.

16. X.Q. Li, D.W. Elliott, and W.X. Zhang, Zero-valent iron nanoparticles for abatement of environmental pollutants: Materials and engineering aspects, Crit. Rev. Solid State Mater. Sci. 31 (2006) 111-122.

17. A.B. Cundy, L. Hopkinson, and R.L.D. Whitby, Use of iron-based technologies in contaminated land and groundwater remediation: A review, Sci. Total Environ. 400 (2008) 42-51.

18. B. Geng, Z. Jin, T. Li, and X. Qi, Preparation of chitosan-stabilized Fe0 nanoparticles for removal of hexavalent chromium in water, Sci. Total Environ. 407 (2009) 4994-5000.

19. B. Schrick, B.W. Hydutsky, J.L. Blough, and T.E. Mallouk, Delivery vehicles for zerovalent metal nanoparticles in soil and groundwater, Chem. Mater. 16 (2004) 2187-2193. 
20. J. Quinn, C. Geiger, C. Clausen, K. Brooks, C. Coon, S. O'Hara, T. Krug, D. Major, W.S. Yoon, A. Gavaskar, and T. Holdsworth, Field demonstration of DNAPL dehalogenation using emulsified zero-valent iron, Environ. Sci. Technol. 39 (2005) 1309-1318.

21. F. He and D. Zhao, Manipulating the size and dispersibility of zerovalent iron nanoparticles by use of carboxymethyl cellulose stabilizers, Environ. Sci. Technol. 41 (2007) 6216-6221.

22. N. Saleh, K. Sirk, Y. Liu, T. Phenrat, B. Dufour, K. Matyjaszewski, R.D. Tilton, and G.V. Lowry, Surface modifications enhance nanoiron transport and NAPL targeting in saturated porous media, Environ. Eng. Sci. 24 (2007) 45-57.

23. M. Elimelech, X. Jia, J. Gregory, and R.A. Williams, in Particle deposition and aggregation: measurement, modelling and simulation 1998, Butterworth-Heinemann Woburn, Massachusetts p. 440.

24. S.R. Kanel, R.R. Goswami, T.P. Clement, M.O. Barnett, and D. Zhao, Two dimensional transport characteristics of surface stabilized zero-valent iron nanoparticles in porous media, Environ. Sci. Technol. 42 (2008) 896-900.

25. T.B. Scott, Inorganic nanoparticles for remediation in Inorganic Nanoparticles: Synthesis, Applications, and Perspectives C. Altavilla and E. Ciliberto, Editors. 2011, CRC Press Boca Raton, FL p. 393-441

26. T. Phenrat, N. Saleh, K. Sirk, R.D. Tilton, and G.V. Lowry, Aggregation and sedimentation of aqueous nanoscale zerovalent iron dispersions, Environ. Sci. Technol. 41 (2007) 284-290.

27. J. Theron, J. Walker, and T. Cloete, Nanotechnology and water treatment: applications and emerging opportunities, Crit. Rev. Microbiol. 34 (2008) 43-69.

28. Y.P. Sun, X.Q. Li, J. Cao, W.X. Zhang, and H.P. Wang, Characterization of zero-valent iron nanoparticles, Adv. Colloid Interface Sci. 120 (2006) 47-56.

29. L. Li, M. Fan, R.C. Brown, J. Van Leeuwen, J. Wang, W. Wang, Y. Song, and P. Zhang, Synthesis, properties, and environmental applications of nanoscale iron-based materials: A review, Crit. Rev. Env. Sci. Technol. 36 (2006) 405-431.

30. F. von der Kammer, P.L. Ferguson, P.A. Holden, A. Masion, K.R. Rogers, S.J. Klaine, A.A. Koelmans, N. Horne, and J.M. Unrine, Analysis of engineered nanomaterials in complex matrices (environment and biota): General considerations and conceptual case studies, Environ. Toxicol. Chem. 31 (2012) 32-49.

31. D.R. Baer, D.J. Gaspar, P. Nachimuthu, S.D. Techane, and D.G. Castner, Application of surface chemical analysis tools for characterization of nanoparticles, Anal Bioanal Chem 396 (2010) 983-1002.

32. M. Hassellöv, J.W. Readman, J.F. Ranville, and K. Tiede, Nanoparticle analysis and characterization methodologies in environmental risk assessment of engineered nanoparticles, Ecotoxicol. 17 (2008) 344-361.

33. P. Christian, F. Von der Kammer, M. Baalousha, and T. Hofmann, Nanoparticles: structure, properties, preparation and behaviour in environmental media, Ecotoxicol. 17 (2008) 326343.

34. L. Signorini, L. Pasquini, L. Savini, R. Carboni, F. Boscherini, E. Bonetti, A. Giglia, M. Pedio, N. Mahne, and S. Nannarone, Size-dependent oxidation in iron/iron oxide core-shell nanoparticles, Phys. Rev. B 68 (2003) 195423.

35. H.S. Kim, J.Y. Ahn, K.Y. Hwang, I.K. Kim, and I. Hwang, Atmospherically stable nanoscale zerovalent iron particles formed under controlled air contact: characteristics and reactivity, Environ. Sci. Technol. 44 (2010) 1760-1766.

36. N. Saleh, T. Phenrat, K. Sirk, B. Dufour, J. Ok, T. Sarbu, K. Matyjaszewski, R.D. Tilton, and G.V. Lowry, Adsorbed triblock copolymers deliver reactive iron nanoparticles to the oil/water interface, Nano Lett. 5 (2005) 2489-2494.

37. S.R. Kanel, D. Nepal, B. Manning, and H. Choi, Transport of surface-modified iron nanoparticle in porous media and application to arsenic (III) remediation, J. Nanopart. Res. 9 (2007) 725-735. 
38. W. Yan, A.A. Herzing, C.J. Kiely, and W.X. Zhang, Nanoscale zero-valent iron (nZVI): Aspects of the core-shell structure and reactions with inorganic species in water, J. Contam. Hydrol. 118 (2010) 96-104.

39. A.B.M. Giasuddin, S.R. Kanel, and H. Choi, Adsorption of humic acid onto nanoscale zerovalent iron and its effect on arsenic removal, Environ. Sci. Technol. 41 (2007) 2022-2027.

40. A. Tiraferri, K.L. Chen, R. Sethi, and M. Elimelech, Reduced aggregation and sedimentation of zero-valent iron nanoparticles in the presence of guar gum, J. Colloid Interface Sci. 324 (2008) 71-79.

41. Y.H. Lin, H.H. Tseng, M.Y. Wey, and M.D. Lin, Characteristics of two types of stabilized nano zero-valent iron and transport in porous media, Sci. Total Environ. 408 (2010) 2260-2267.

42. Y.H. Hwang, D.G. Kim, and H.S. Shin, Effects of synthesis conditions on the characteristics and reactivity of nano scale zero valent iron, Appl. Catal., B 105 (2011) 144-150.

43. F. He, D. Zhao, J. Liu, and C.B. Roberts, Stabilization of Fe - Pd nanoparticles with sodium carboxymethyl cellulose for enhanced transport and dechlorination of trichloroethylene in soil and groundwater, Ind. Eng. Chem. Res. 46 (2007) 29-34.

44. C.M. Cirtiu, T. Raychoudhury, S. Ghoshal, and A. Moores, Systematic comparison of the size, surface characteristics and colloidal stability of zero valent iron nanoparticles pre- and postgrafted with common polymers, Colloids Surf., A 390 (2011) 95-104.

45. J.R. Lead and K.J. Wilkinson, Aquatic colloids and nanoparticles: current knowledge and future trends, Environ. Chem. 3 (2006) 159-171.

46. R.F. Domingos, M.A. Baalousha, Y. Ju-Nam, M.M. Reid, N. Tufenkji, J.R. Lead, G.G. Leppard, and K.J. Wilkinson, Characterizing manufactured nanoparticles in the environment: multimethod determination of particle sizes, Environ Sci Technol 43 (2009) 7277-7284.

47. A. Jillavenkatesa, S.J. Dapkunas, and L.-S.H. Lum, Special Publication 960-1: Partice Size Characterisation in NIST Recommended Practice Guide (2001) National Institute of Standards and Technology.

48. C. Singh, S. Friedrichs, M. Levin, R. Birkedal, K.A. Jensen, G. Pojana, W. Wohlleben, S. Schulte, K. Wiench, T. Turney, O. Koulaeva, D. Marshall, K. Hund-Rinke, W. Kördel, E. Van Doren, P.-J. De Temmerman, M. Abi Daoud Francisco, J. Mast, N. Gibson, R. Koeber, T. Linsinger, and C.L. Klein, Zinc Oxide NM-110, NM-111, NM-112, NM-113 Characterisation and Test Item Preparation in NM-Series of Representative Manufactured Nanomaterials (2011) JRS Institute for Reference Materials and Measurements.

49. C.L. Klein, Comero, B. Stahlmecke, J. Romazanov, T.A.J. Kuhlbusch, E. Van Doren, P.-J. De Temmerman, J. Mast, P. Wick, H.F. Krug, G. Locoro, K. Hund-Rinke, W. Kördel, S. Friedrichs, G. Maier, J. Werner, T. Linsinger, and B.M. Gawlik, NM-300 Silver Characterisation, Stability, Homogeneity in NM-Series of Representative Manufactured Nanomaterials (2011) JRS Institute for Health and Consumer Protection.

50. W.S. Rasband, ImageJ, 1997-2012, U.S. National Institutes of Health: Bethesda, Maryland, USA.

51. R. Yuvakkumar, V. Elango, V. Rajendran, and N. Kannan, Preparation and characterization of zero valent Iron nanoparticles, Dig. J. Nano. Biost. 6 (2011) 1771-1776.

52. L.N. Shi, Y.M. Lin, X. Zhang, and Z.L. Chen, Synthesis, characterization and kinetics of bentonite supported $\mathrm{nZVI}$ for the removal of $\mathrm{Cr}(\mathrm{VI})$ from aqueous solution, Chem. Eng. J. 171 (2011) 612-617.

53. S.R. Kanel, B. Manning, L. Charlet, and H. Choi, Removal of arsenic (III) from groundwater by nanoscale zero-valent iron, Environ. Sci. Technol. 39 (2005) 1291-1298.

54. H.C. Choi, A.B.M. Giasuddin, and S.R. Kanel, Method of synthesizing air-stable zero-valent iron nanoparticles at room temperature and applications, 2007, Google Patents.

55. J. WooáLee and S. BináKim, Enhanced $\mathrm{Cr}(\mathrm{VI})$ removal using iron nanoparticle decorated graphene, Nanoscale 3 (2011) 3583-3585. 
56. C.M. Wang, D.R. Baer, J.E. Amonette, M.H. Engelhard, Y. Qiang, and J. Antony, Morphology and oxide shell structure of iron nanoparticles grown by sputter-gas-aggregation, Nanotechnol. 18 (2007) 255603.

57. C.M. Wang, D.R. Baer, J.E. Amonette, M.H. Engelhard, J. Antony, and Y. Qiang, Electron beam-induced thickening of the protective oxide layer around Fe nanoparticles, Ultramicroscopy 108 (2007) 43-51.

58. H.G. Cha, Y.H. Kim, C.W. Kim, and Y.S. Kang, Preparation of aqueous dispersion of colloidal $\alpha-$ Fe nanoparticle by phase transfer, Sens. Actuators, B 126 (2007) 221-225.

59. J.T. Nurmi, P.G. Tratnyek, V. Sarathy, D.R. Baer, J.E. Amonette, K. Pecher, C. Wang, J.C. Linehan, D.W. Matson, R.L. Penn, and M.D. Driessen, Characterization and Properties of Metallic Iron Nanoparticles: Spectroscopy, Electrochemistry, and Kinetics, Environ Sci Technol 39 (2004) 1221-1230.

60. C. Wang, D.R. Baer, J.E. Amonette, M.H. Engelhard, J. Antony, and Y. Qiang, Morphology and Electronic Structure of the Oxide Shell on the Surface of Iron Nanoparticles, J Am Chem Soc 131 (2009) 8824-8832.

61. Q. Wang, S. Lee, and H. Choi, Aging study on the structure of Fe0-nanoparticles: stabilization, characterization, and reactivity, The J. Phy. Chem., C 114 (2010) 2027-2033.

62. J.E. Martin, A.A. Herzing, W. Yan, X.Q. Li, B.E. Koel, C.J. Kiely, and W.X. Zhang, Determination of the oxide layer thickness in core-shell zerovalent iron nanoparticles, Langmuir 24 (2008) 4329-4334.

63. W. Yan, A.A. Herzing, X.Q. Li, C.J. Kiely, and W.X. Zhang, Structural evolution of Pd-doped nanoscale zero-valent iron (nZVI) in aqueous media and implications for particle aging and reactivity, Environ. Sci. Technol. 44 (2010) 4288-4294.

64. W. Yan, R. Vasic, A.I. Frenkel, and B.E. Koel, Intraparticle reduction of arsenite (As (III)) by nanoscale zerovalent iron (nZVI) investigated with in situ X-ray absorption spectroscopy, Environ. Sci. Technol. 46 (2012) 7018-7026.

65. L. Ling and W.X. Zhang, Reactions of nanoscale zero-valent iron with Ni (II): threedimensional tomography of the "hollow out" effect in a single nanoparticle, Environ. Sci. Technol. Lett. 1 (2014) 209-213.

66. A.H. Latham and M.E. Williams, Transmission Electron Microscope-Induced Structural Evolution in Amorphous Fe, Co, and Ni Oxide Nanoparticles, Langmuir 24 (2008) 1419514202.

67. R.D. Glover, J.M. Miller, and J.E. Hutchison, Generation of Metal Nanoparticles from Silver and Copper Objects: Nanoparticle Dynamics on Surfaces and Potential Sources of Nanoparticles in the Environment, ACS Nano 5 (2011) 8950-8957.

68. S.R. Kanel, J.M. Greneche, and H. Choi, Arsenic (V) removal from groundwater using nano scale zero-valent iron as a colloidal reactive barrier material, Environ. Sci. Technol. 40 (2006) 2045-2050.

69. J. Su, S. Lin, Z. Chen, M. Megharaj, and R. Naidu, Dechlorination of p-chlorophenol from aqueous solution using bentonite supported Fe/Pd nanoparticles: Synthesis, characterization and kinetics, Desalination 280 (2011) 167-173.

70. Ç. Üzüm, T. Shahwan, A.E. Eroğlu, K.R. Hallam, T.B. Scott, and I. Lieberwirth, Synthesis and characterization of kaolinite-supported zero-valent iron nanoparticles and their application for the removal of aqueous $\mathrm{Cu} 2+$ and Co 2+ ions, Appl. Clay Sci. 43 (2009) 172-181.

71. X. Wu, Q. Yang, D. Xu, Y. Zhong, K. Luo, X. Li, H. Chen, and G. Zeng, Simultaneous adsorption/reduction of bromate by nanoscale zerovalent iron supported on modified activated carbon, Ind. Eng. Chem. Res. 52 (2013) 12574-12581.

72. A.N. Bezbaruah, S. Krajangpan, B.J. Chisholm, E. Khan, and J.J.E. Bermudez, Entrapment of iron nanoparticles in calcium alginate beads for groundwater remediation applications, J. Hazard. Mater. 166 (2009) 1339-1343. 
73. S.C.G. Kiruba Daniel, G. Vinothini, N. Subramanian, K. Nehru, and M. Sivakumar, Biosynthesis of $\mathrm{Cu}, \mathrm{ZVI}$, and $\mathrm{Ag}$ nanoparticles using Dodonaea viscosa extract for antibacterial activity against human pathogens, J. Nanopart. Res. 15 (2012) 1-10.

74. Y.-T. Lin, C.-H. Weng, and F.-Y. Chen, Effective removal of AB24 dye by nano/micro-size zerovalent iron, Sep. Purif. Technol. 64 (2008) 26-30.

75. S.R. Qiu, H.F. Lai, M.J. Roberson, M.L. Hunt, C. Amrhein, L.C. Giancarlo, G.W. Flynn, and J.A. Yarmoff, Removal of Contaminants from Aqueous Solution by Reaction with Iron Surfaces, Langmuir 16 (2000) 2230-2236.

76. A.R. Badireddy, M.R. Wiesner, and J. Liu, Detection, characterization, and abundance of engineered nanoparticles in complex waters by hyperspectral imagery with enhanced darkfield microscopy, Environ. Sci. Technol. 46 (2012) 10081-10088.

77. M.G. Gustafsson, Surpassing the lateral resolution limit by a factor of two using structured illumination microscopy, J. Microsc. 198 (2000) 82-87.

78. D. Baddeley, C. Batram, Y. Weiland, C. Cremer, and U.J. Birk, Nanostructure analysis using spatially modulated illumination microscopy, Nat. Protoc. 2 (2007) 2640-2646.

79. M.J. Rust, M. Bates, and X. Zhuang, Sub-diffraction-limit imaging by stochastic optical reconstruction microscopy (STORM), Nat. Methods 3 (2006) 793-796.

80. B. Ward, J.A. Notte, and N. Economou, Helium ion microscope: A new tool for nanoscale microscopy and metrology, J. Vac. Sci. Technol., B 24 (2006) 2871-2874.

81. M. Kaur, J.S. McCloy, W. Jiang, Q. Yao, and Y. Qiang, Size dependence of inter-and intracluster interactions in core-shell iron-iron oxide nanoclusters, The J. Phy. Chem., C 116 (2012) 12875-12885.

82. P. Schurtenberger and M.E. Newman, Characterization of biological and environmental particles using static and dynamic light scattering, Environ. Part. 2 (1993) 37-115.

83. M. Farré, J. Sanchís, and D. Barceló, Analysis and assessment of the occurrence, the fate and the behavior of nanomaterials in the environment, TrAC, Trends Anal. Chem. 30 (2011) 517527.

84. A. Ledin, S. Karlsson, A. Düker, and B. Allard, Measurements $<i>$ in situ $</ i>$ of concentration and size distribution of colloidal matter in deep groundwaters by photon correlation spectroscopy, Water Res. 28 (1994) 1539-1545.

85. L. Honetschlagerova, P. Janouskovcova, and Z. Soffer, NANOSCALE ZERO VALENT IRON COATING FOR SUBSURFACE APPLICATION, in Nanocon 20122012: Brno, Czech Republic.

86. T. Phenrat, H.J. Kim, F. Fagerlund, T. Illangasekare, R.D. Tilton, and G.V. Lowry, Particle size distribution, concentration, and magnetic attraction affect transport of polymer-modified Fe0 nanoparticles in sand columns, Environ. Sci. Technol. 43 (2009) 5079-5085.

87. Y.H. Shih, C.Y. Hsu, and Y.F. Su, Reduction of hexachlorobenzene by nanoscale zero-valent iron: kinetics, pH effect, and degradation mechanism, Sep. Purif. Technol. 76 (2011) 268-274.

88. H.J. Kim, T. Phenrat, R.D. Tilton, and G.V. Lowry, Effect of kaolinite, silica fines and pH on transport of polymer-modified zero valent iron nano-particles in heterogeneous porous media, J. Colloid Interface Sci. 370 (2012) 1-10.

89. J. Fatisson, S. Ghoshal, and N. Tufenkji, Deposition of carboxymethylcellulose-coated zerovalent iron nanoparticles onto silica: Roles of solution chemistry and organic molecules, Langmuir 26 (2010) 12832-12840.

90. C.M. Kocur, D.M. O'Carroll, and B.E. Sleep, Impact of nZVI stability on mobility in porous media, J. Contam. Hydrol. (2012)

91. M. Filella, J. Zhang, M.E. Newman, and J. Buffle, Analytical applications of photon correlation spectroscopy for size distribution measurements of natural colloidal suspensions: capabilities and limitations, Colloids Surf., A 120 (1997) 27-46.

92. P.C. Hiemenz and R. Rajagopalan, Principles of Colloid and Surface Chemistry, revised and expanded. Vol. 14. 1997: CRC Press. 
93. S.M. Ponder, J.G. Darab, and T.E. Mallouk, Remediation of $\mathrm{Cr}(\mathrm{VI})$ and $\mathrm{Pb}(\mathrm{II})$ aqueous solutions using supported, nanoscale zero-valent iron, Environ. Sci. Technol. 34 (2000) 25642569.

94. H. Weinberg, A. Galyean, and M. Leopold, Evaluating engineered nanoparticles in natural waters, TrAC, Trends Anal. Chem. 30 (2011) 72-83.

95. C.W. Isaacson and D. Bouchard, Asymmetric flow field flow fractionation of aqueous $\mathrm{C}_{60}$ nanoparticles with size determination by dynamic light scattering and quantification by liquid chromatography atmospheric pressure photo-ionization mass spectrometry, J. Chromatogr. A 1217 (2010) 1506-1512.

96. L.H. Hanus and H.J. Ploehn, Conversion of intensity-averaged photon correlation spectroscopy measurements to number-averaged particle size distributions. 1 . Theoretical development, Langmuir 15 (1999) 3091-3100.

97. R. Finsy, Particle sizing by quasi-elastic light scattering, Adv. Colloid Interface Sci. 52 (1994) 79-143.

98. D. O'Carroll, B. Sleep, M. Krol, H. Boparai, and C. Kocur, Nanoscale zero valent iron and bimetallic particles for contaminated site remediation, AdWR (2012)

99. K.D. Grieger, A. Fjordboge, N.B. Hartmann, E. Eriksson, P.L. Bjerg, and A. Baun, Environmental benefits and risks of zero-valent iron nanoparticles (nZVI) for in situ remediation: Risk mitigation or trade-off?, J. Contam. Hydrol. 118 (2010) 165-183.

100. K.S. Lin, N.B. Chang, and T.D. Chuang, Fine structure characterization of zero-valent iron nanoparticles for decontamination of nitrites and nitrates in wastewater and groundwater, Sci. Technol. Adv. Mater. 9 (2008) 025015.

101. Y. Xi, M. Mallavarapu, and R. Naidu, Reduction and adsorption of $\mathrm{Pb}^{2+}$ in aqueous solution by nano-zero-valent iron-a SEM, TEM and XPS study, Mater. Res. Bull. 45 (2010) 1361-1367.

102. M. Dickinson and T.B. Scott, The application of zero-valent iron nanoparticles for the remediation of a uranium-contaminated waste effluent, J. Hazard. Mater. 178 (2010) 171179.

103. Q. Wang, S. Snyder, J. Kim, and H. Choi, Aqueous ethanol modified nanoscale zerovalent iron in bromate reduction: synthesis, characterization, and reactivity, Environ. Sci. Technol. 43 (2009) 3292-3299.

104. S. Li, W. Yan, and W.X. Zhang, Solvent-free production of nanoscale zero-valent iron (nZVI) with precision milling, Green Chem. 11 (2009) 1618-1626.

105. T. Zheng, J. Zhan, J. He, C. Day, Y. Lu, G.L. McPherson, G. Piringer, and V.T. John, Reactivity Characteristics of Nanoscale Zerovalent Iron-Silica Composites for Trichloroethylene Remediation, Environ Sci Technol 42 (2008) 4494-4499.

106. J.T. Nurmi, P.G. Tratnyek, V. Sarathy, D.R. Baer, J.E. Amonette, K. Pecher, C. Wang, J.C. Linehan, D.W. Matson, and R.L. Penn, Characterization and properties of metallic iron nanoparticles: spectroscopy, electrochemistry, and kinetics, Environmental Science \& Technology 39 (2005) 1221-1230.

107. S.M. Ponder, J.G. Darab, J. Bucher, D. Caulder, I. Craig, L. Davis, N. Edelstein, W. Lukens, H. Nitsche, L. Rao, D.K. Shuh, and T.E. Mallouk, Surface Chemistry and Electrochemistry of Supported Zerovalent Iron Nanoparticles in the Remediation of Aqueous Metal Contaminants, Chem. Mater. 13 (2001) 479-486.

108. J. Leveneur, G.I. Waterhouse, J. Kennedy, J.B. Metson, and D.R. Mitchell, Nucleation and growth of Fe nanoparticles in $\mathrm{SiO}_{2}$ : a TEM, XPS, and Fe L-edge XANES investigation, The J. Phy. Chem., C 115 (2011) 20978-20985.

109. B.C. Reinsch, B. Forsberg, R.L. Penn, C.S. Kim, and G.V. Lowry, Chemical Transformations during Aging of Zerovalent Iron Nanoparticles in the Presence of Common Groundwater Dissolved Constituents, Environ Sci Technol 44 (2010) 3455-3461. 
110. W. Yan, A.A. Herzing, C.J. Kiely, and W. Zhang, Nanoscale zero-valent iron (nZVI): Aspects of the core-shell structure and reactions with inorganic species in water, J. Contam. Hydrol. 118 (2010) 96-104.

111. Y.P. Sun, X.Q. Li, W.X. Zhang, and H.P. Wang, A method for the preparation of stable dispersion of zero-valent iron nanoparticles, Colloids Surf., A 308 (2007) 60-66.

112. Y. Liu and B. Yan, Characterizing the surface chemistry of nanoparticles: an analogy to solidphase synthesis samples, Comb. Chem. High Throughput Screening 14 (2011) 191-197.

113. Q. Wang, S. Kanel, H. Park, A. Ryu, and H. Choi, Controllable synthesis, characterization, and magnetic properties of nanoscale zerovalent iron with specific high Brunauer-EmmettTeller surface area, J Nanopart Res 11 (2009) 749-755.

114. L.S. Wang and R.Y. Hong, Synthesis, Surface Modification and Characterisation of Nanoparticles, in Advances in Nanocomposites - Synthesis, Characterization and Industrial Applications, D.B. Reddy, Editor 2011.

115. B.E. Warren, X-ray Diffraction1969: Courier Corporation.

116. H.P. Klug and L.E. Alexander, X-ray diffraction procedures, (1954)

117. Z. Fang, J. Chen, X. Qiu, X. Qiu, W. Cheng, and L. Zhu, Effective removal of antibiotic metronidazole from water by nanoscale zero-valent iron particles, Desalination 268 (2011) 60-67.

118. M.R. Jamei, M.R. Khosravi, and B. Anvaripour, A novel ultrasound assisted method in synthesis of NZVI particles, Ultrason. Sonochem. 21 (2014) 226-233.

119. A.R. Esfahani, A.F. Firouzi, G. Sayyad, and A. Kiasat, Transport and retention of polymerstabilized zero-valent iron nanoparticles in saturated porous media: Effects of initial particle concentration and ionic strength, J. Ind. Eng. Chem. 20 (2013) 2671-2679.

120. D. Karabelli, C.a.r. Üzüm, T. Shahwan, A.E. Eroglu, T.B. Scott, K.R. Hallam, and I. Lieberwirth, Batch removal of aqueous $\mathrm{Cu}^{2+}$ ions using nanoparticles of zero-valent iron: a study of the capacity and mechanism of uptake, Ind. Eng. Chem. Res. 47 (2008) 4758-4764.

121. Y.C. Lee, C.W. Kim, J.Y. Lee, H.J. Shin, and J.W. Yang, Characterization of nanoscale zero valent iron modified by nonionic surfactant for trichloroethylene removal in the presence of humic acid: A research note, Desalin. Water Treat. 10 (2009) 33-38.

122. S.N. Zhu, G.H. Liu, Z. Ye, Q. Zhao, and Y. Xu, Reduction of dinitrotoluene sulfonates in TNT red water using nanoscale zerovalent iron particles, Environ. Sci. Pollut. Res. 19 (2012) 23722380.

123. C. He, J. Yang, L. Zhu, Q. Zhang, W. Liao, S. Liu, Y. Liao, M.A. Asi, and D. Shu, pH-dependent degradation of acid orange II by zero-valent iron in presence of oxygen, Sep. Purif. Technol. 117 (2013) 59-68.

124. H. Dong, X. Guan, and I.M. Lo, Fate of As (V)-treated nano zero-valent iron: determination of arsenic desorption potential under varying environmental conditions by phosphate extraction, Water Res. 46 (2012) 4071-4080.

125. Ç. Üzüm, T. Shahwan, A. Eroğlu, I. Lieberwirth, T. Scott, and K. Hallam, Application of zerovalent iron nanoparticles for the removal of aqueous $\mathrm{Co} 2+$ ions under various experimental conditions, Chem. Eng. J. 144 (2008) 213-220.

126. S. Machado, J.G. Pacheco, H.P.A. Nouws, J.T. Albergaria, and C. Delerue-Matos, Characterization of green zero-valent iron nanoparticles produced with tree leaf extracts, Sci. Total Environ. 533 (2015) 76-81.

127. E.C. Njagi, H. Huang, L. Stafford, H. Genuino, H.M. Galindo, J.B. Collins, G.E. Hoag, and S.L. Suib, Biosynthesis of iron and silver nanoparticles at room temperature using aqueous sorghum bran extracts, Langmuir 27 (2011) 264-271.

128. T. Shahwan, S. Abu Sirriah, M. Nairat, E. Boyaci, A.E. Eroĝlu, T.B. Scott, and K.R. Hallam, Green synthesis of iron nanoparticles and their application as a Fenton-like catalyst for the degradation of aqueous cationic and anionic dyes, Chem. Eng. J. 172 (2011) 258-266. 
129. D.R. Baer, J.E. Amonette, M.H. Engelhard, D.J. Gaspar, A.S. Karakoti, S. Kuchibhatla, P. Nachimuthu, J.T. Nurmi, Y. Qiang, V. Sarathy, S. Seal, A. Sharma, P.G. Tratnyek, and C.M. Wang, Characterization challenges for nanomaterials, Surf. Interface Anal. 40 (2008) 529537.

130. D.R. Baer and M.H. Engelhard, XPS analysis of nanostructured materials and biological surfaces, J. Electron. Spectrosc. Relat. Phenom. 178-179 (2010) 415-432.

131. I.M. Kempson, W.M. Skinner, and P. Kirkbride, Calcium distributions in human hair by ToFSIMS, Biochim. Biophys. Acta-General Subjects 1624 (2003) 1-5.

132. S.R. Grano, M. Sollaart, W. Skinner, C.A. Prestidge, and J. Ralston, Surface modifications in the chalcopyrite-sulphite ion system. I. collectorless flotation, XPS and dissolution study, Int. J. Miner. Process. 50 (1997) 1-26.

133. S.R. Grano, H. Cnossen, W. Skinner, C.A. Prestidge, and J. Ralston, Surface modifications in the chalcopyrite-sulphite ion system, II. Dithiophosphate collector adsorption study, Int. J. Miner. Process. 50 (1997) 27-45.

134. A.S. Karakoti, L.L. Hench, and S. Seal, The potential toxicity of nanomaterials -The role of surfaces, JOM 58 (2006) 77-82.

135. N.H. Turner, B.I. Dunlap, and R.J. Colton, Surface analysis: $x$-ray photoelectron spectroscopy, Auger electron spectroscopy and secondary ion mass spectrometry, Anal. Chem. 56 (1984) 373R-416R.

136. D.R. Baer, P.G. Tratnyek, Y. Qiang, J.E. Amonette, J. Linehan, V. Sarathy, J.T. Nurmi, C. Wang, and J. Anthony, Synthesis, Characterisation, and properties of zero-valent iron nanoparticles, in Environmental applications of nanomaterials; synthesis, sorbents and sensors, G.E. Fryxell and G. Cao, Editors. 2012, Imperial College Press: London.

137. A.M. Venezia, X-ray photoelectron spectroscopy (XPS) for catalysts characterization, Catal. Today 77 (2003) 359-370.

138. M. Grafe, E. Donner, R.N. Collins, and E. Lombi, Speciation of metal(loid)s in environmental samples by X-ray absorption spectroscopy: A critical review, Anal. Chim. Acta 822 (2014) 22.

139. J. Prietzel, J. Thieme, K. Eusterhues, and D. Eichert, Iron speciation in soils and soil aggregates by synchrotron-based X-ray microspectroscopy (XANES, $\mu$-XANES), Eur. J. Soil Sci. 58 (2007) 1027-1041.

140. J. Feldmann, P. Salaün, and E. Lombi, Critical review perspective: elemental speciation analysis methods in environmental chemistry-moving towards methodological integration, Environ. Chem. 6 (2009) 275-289.

141. E. Lombi and J. Susini, Synchrotron-based techniques for plant and soil science: opportunities, challenges and future perspectives, Plant Soil 320 (2009) 1-35.

142. T. Phenrat, N. Saleh, K. Sirk, R.D. Tilton, and G.V. Lowry, Aggregation and sedimentation of aqueous nanoscale zerovalent iron dispersions, Environ. Sci. Technol. 41 (2007) 284-290.

143. L.F. Greenlee, J.D. Torrey, R.L. Amaro, and J.M. Shaw, Kinetics of Zero Valent Iron Nanoparticle Oxidation in Oxygenated Water, Environ Sci Technol 46 (2012) 12913-12920.

144. G.C. Allen, M.T. Curtis, A.J. Hooper, and P.M. Tucker, X-Ray photoelectron spectroscopy of iron-oxygen systems, J. Chem. Soc., Dalton Trans. 0 (1974) 1525-1530.

145. J.N. Fiedor, W.D. Bostick, R.J. Jarabek, and J. Farrell, Understanding the Mechanism of Uranium Removal from Groundwater by Zero-Valent Iron Using X-ray Photoelectron Spectroscopy, Environ Sci Technol 32 (1998) 1466-1473.

146. B. Ravel and M. Newville, ATHENA, ARTEMIS, HEPHAESTUS: data analysis for $x$-ray absorption spectroscopy using IFEFFIT., J. Synchrotron Radiat. 12 (2005) 537-541.

147. T. Ressler, WinXAS: a program for X-ray absorption spectroscopy data analysis under MSWindows, J. Synchrotron Radiat. 5 (1998) 118-122.

148. G.V. Lowry, K.B. Gregory, S.C. Apte, and J.R. Lead, Transformations of nanomaterials in the environment, Environ Sci Technol 46 (2012) 6893-6899. 
149. F. Gottschalk, T. Sonderer, R.W. Scholz, and B. Nowack, Possibilities and limitations of modeling environmental exposure to engineered nanomaterials by probabilistic material flow analysis, Environ. Toxicol. Chem. 29 (2010) 1036-1048.

150. H. Dong and I. Lo, Influence of humic acid on the colloidal stability of surface-modified nano zero-valent iron, Water Res. 47 (2013) 419-427.

151. A.R. Esfahani, A.F. Firouzi, G. Sayyad, and A. Kiasat, Transport and retention of polymerstabilized zero-valent iron nanoparticles in saturated porous media: Effects of initial particle concentration and ionic strength, J. Ind. Eng. Chem. (2013)

152. R.L. Johnson, G.O.B. Johnson, J.T. Nurmi, and P.G. Tratnyek, Natural organic matter enhanced mobility of nano zerovalent iron, Environ. Sci. Technol. 43 (2009) 5455-5460.

153. T. Raychoudhury, N. Tufenkji, and S. Ghoshal, Aggregation and deposition kinetics of carboxymethyl cellulose-modified zero-valent iron nanoparticles in porous media, Water Res. 46 (2012) 1735-1744.

154. Y. Xie and D.M. Cwiertny, Influence of anionic cosolutes and pH on nanoscale zerovalent iron longevity: time scales and mechanisms of reactivity loss toward 1, 1, 1, 2-tetrachloroethane and $\mathrm{Cr}$ (VI), Environ. Sci. Technol. 46 (2012) 8365-8373.

155. K. Yin, I. Lo, H. Dong, P. Rao, and M.S. Mak, Lab-scale simulation of the fate and transport of nano zero-valent iron in subsurface environments: Aggregation, sedimentation, and contaminant desorption, J. Hazard. Mater. 227 (2012) 118-125.

156. A.S. Adeleye, A.A. Keller, R.J. Miller, and H.S. Lenihan, Persistence of commercial nanoscaled zero-valent iron (nZVI) and by-products, J. Nanopart. Res. 15 (2013)

157. K.W. Henn and D.W. Waddill, Utilization of nanoscale zero-valent iron for source remediation: A case study, Rem. J. 16 (2006) 57-77.

158. Y.T. Wei, S.C. Wu, C.M. Chou, C.H. Che, S.M. Tsai, and H.L. Lien, Influence of nanoscale zerovalent iron on geochemical properties of groundwater and vinyl chloride degradation: a field case study, Water Res. 44 (2010) 131-140.

159. F. He, D. Zhao, and C. Paul, Field assessment of carboxymethyl cellulose stabilized iron nanoparticles for in situ destruction of chlorinated solvents in source zones, Water Res. 44 (2010) 2360-2370.

160. P. Bennett, F. He, D. Zhao, B. Aiken, and L. Feldman, In situ testing of metallic iron nanoparticle mobility and reactivity in a shallow granular aquifer, J. Contam. Hydrol. 116 (2010) 35-46.

161. C.M. Kocur, A.I. Chowdhury, N. Sakulchaicharoen, H.K. Boparai, K.P. Weber, P. Sharma, M.M. Krol, L.M. Austrins, C. Peace, and B.E. Sleep, Characterization of nZVI mobility in a field scale test, Environ. Sci. Technol. (2014)

162. R.L. Johnson, J.T. Nurmi, G.S. O'Brien Johnson, D. Fan, R.L. O'Brien Johnson, Z. Shi, A.J. SalterBlanc, P.G. Tratnyek, and G.V. Lowry, Field-scale transport and transformation of carboxymethylcellulose-stabilized nano zero-valent iron, Environ. Sci. Technol. 47 (2013) 1573-1580.

163. Z. Shi, J.T. Nurmi, and P.G. Tratnyek, Effects of nano zero-valent iron on oxidation- reduction potential, Environ. Sci. Technol. 45 (2011) 1586-1592.

164. S. Arepalli, P. Nikolaev, O. Gorelik, V.G. Hadjiev, W. Holmes, B. Files, and L. Yowell, Protocol for the characterization of single-wall carbon nanotube material quality, Carbon 42 (2004) 1783-1791.

165. J. Decker, A.H. Walker, K. Bosnick, C. Clifford, L. Dai, J. Fagan, S. Hooker, Z. Jakubek, C. Kingston, and J. Makar, Sample preparation protocols for realization of reproducible characterization of single-wall carbon nanotubes, Metrologia 46 (2009) 682.

166. Y. Xie and D.M. Cwiertny, Use of dithionite to extend the reactive lifetime of nanoscale zerovalent iron treatment systems, Environ. Sci. Technol. 44 (2010) 8649-8655. 
167. H. Dong, X. Guan, and I.M.C. Lo, Fate of As(V)-treated nano zero-valent iron: Determination of arsenic desorption potential under varying environmental conditions by phosphate extraction, Water Res. 46 (2012) 4071-4080.

168. T. Rojas, J. Sanchez-Lopez, J. Greneche, A. Conde, and A. Fernandez, Characterization of oxygen passivated iron nanoparticles and thermal evolution to $y-\mathrm{Fe}_{2} \mathrm{O}_{3}$, Journal of materials science 39 (2004) 4877-4885.

169. Y. Zhang, Y. Su, X. Zhou, C. Dai, and A.A. Keller, A new insight on the core-shell structure of zerovalent iron nanoparticles and its application for $\mathrm{Pb}$ (II) sequestration, J. Hazard. Mater. 263 (2013) 685-693.

170. D.R. Baer and M.H. Engelhard, XPS analysis of nanostructured materials and biological surfaces, J. Electron. Spectrosc. Relat. Phenom. 178 (2010) 415-432.

171. Q. Wang, S.R. Kanel, H. Park, A. Ryu, and H. Choi, Controllable synthesis, characterization, and magnetic properties of nanoscale zerovalent iron with specific high Brunauer-EmmettTeller surface area, J. Nanopart. Res. 11 (2009) 749-755.

172. A. Liu, J. Liu, B. Pan, and W.-x. Zhang, Formation of lepidocrocite ( $\gamma$-FeOOH) from oxidation of nanoscale zero-valent iron (nZVI) in oxygenated water, Rsc Advances 4 (2014) 5737757382.

173. D. Drouin, A.R. Couture, D. Joly, X. Tastet, V. Aimez, and R. Gauvin, CASINO V2. 42-A fast and easy-to-use modeling tool for scanning electron microscopy and microanalysis users, Scanning 29 (2007) 92-101. 


\section{List of Tables:}

Table 1: Summary of studies that have used DLS for nZVI characterisation.

Table 2: Summary of studies that have used XRD for nZVI characterisation.

Table 3: Examples of studies that have used XPS and XAS for nZVI characterisation.

Table 4: Physical and chemical properties of commercial nZVI/ZVI products as reported by the manufacturers.

Table 5: Iron content of the 5 commercial nZVI/ZVI products: Comparison between the manufacturers' data and XRD analysis.

Table 6: Linear combination fitting of the XAS data for the 5 commercial nZVI/ZVI products tested. Species proportions are presented as percentages. Goodness of fit is indicated by the $\chi^{2}$ value.

Table 7: Coordination parameters of Fe in the samples.

Table 8: Examples of characterisation studies investigating the behaviour of nZVI in different aqueous media. 
Table 1: Summary of the different studies that have used DLS to characterise nZVI.

\begin{tabular}{|c|c|c|c|c|c|c|c|c|}
\hline nZVI source & $\begin{array}{c}\text { Coating } \\
\text { material(s) }\end{array}$ & $\begin{array}{c}\text { Sample preparation } \\
\text { before } \\
\text { measurement }\end{array}$ & Concentration & $\begin{array}{l}\text { Type of size } \\
\text { average }\end{array}$ & \multicolumn{2}{|c|}{ Hydrodynamic diameter (nm) } & Observations & Ref. \\
\hline $\begin{array}{l}\text { NANOFER } 25 \\
\text { provided by } \\
\text { NANOIRON Ltd. }\end{array}$ & $\begin{array}{l}\text { Tetraethyl } \\
\text { orthosilicate } \\
\text { (TEOS)-PVP }\end{array}$ & $\begin{array}{c}\text { Samples were } \\
\text { sonicated for different } \\
\text { time periods }\end{array}$ & Not specified & Not specified & \multicolumn{2}{|r|}{$\sim 300$} & $\begin{array}{l}\text { No further effect of } \\
\text { sonication when } \\
\text { applied for more than } \\
15 \text { minutes }\end{array}$ & {$[85]$} \\
\hline \multirow{6}{*}{$\begin{array}{c}\text { Reactive nanoscale } \\
\text { iron particle (RNIP) } \\
\text { provided by Toda } \\
\text { Kyogo }\end{array}$} & \multirow{6}{*}{$\begin{array}{l}\text { PSS (3 different } \\
\text { PSS-coated } \\
\text { nZVI were } \\
\text { prepared) }\end{array}$} & \multirow{6}{*}{$\begin{array}{l}\text { Solution was pre- } \\
\text { fractionated and then } \\
\text { diluted in DI water and } \\
\text { sonicated for } 3 \\
\text { minutes }\end{array}$} & \multirow{6}{*}{$5 \mathrm{mg} \mathrm{L}^{-1}$} & \multirow{3}{*}{$\begin{array}{c}\text { Volume } \\
\text { weighted }\end{array}$} & 1 & $45.6(6 \%) / 328(94 \%)$ & \multirow{6}{*}{$\begin{array}{c}\text { Bimodal size } \\
\text { distribution was } \\
\text { observed for samples } \\
\text { containing larger } \\
\text { aggregates. Number } \\
\text { weighted data reached } \\
\text { lower particle size. }\end{array}$} & \multirow{6}{*}[86]{} \\
\hline & & & & & 2 & $25(40 \%) / 367(60 \%)$ & & \\
\hline & & & & & 3 & $24(100 \%)$ & & \\
\hline & & & & \multirow{3}{*}{$\begin{array}{l}\text { Number } \\
\text { weighted }\end{array}$} & 1 & $26(98 \%) / 263(2 \%)$ & & \\
\hline & & & & & 2 & $15(100 \%)$ & & \\
\hline & & & & & 3 & $16(100 \%)$ & & \\
\hline \multirow{5}{*}{$\begin{array}{l}\text { Bare and sodium } \\
\text { polyaspartate- } \\
\text { coated reactive } \\
\text { nanoscale iron } \\
\text { particle (RNIP and } \\
\text { MRNIP) provided by } \\
\text { Toda Kyogo }\end{array}$} & \multirow{5}{*}{$\begin{array}{l}\text { PMAA-PMMA- } \\
\text { PSS triblock } \\
\text { copolymers or } \\
\text { SDBS } \\
\text { surfactant }\end{array}$} & \multirow{5}{*}{$\begin{array}{l}\text { Solution was sonicated } \\
\text { with ultrasonic probe } \\
\text { for } 30 \text { minutes and } \\
\text { then rotated at } 30 \mathrm{rpm} \\
\text { with an end-over-end } \\
\text { rotator for at least } 72 \\
\text { hours before } \\
\text { measurements }\end{array}$} & \multirow{5}{*}{$30 \mathrm{mg} \mathrm{L}^{-1}$} & \multirow{5}{*}{$\begin{array}{l}\text { Intensity } \\
\text { weighted }\end{array}$} & Bare RNIP & $146 \pm 4$ & $\begin{array}{c}\text { Larger size than the } \\
\text { average primary } \\
\text { particle size determined } \\
\text { from TEM } \\
\text { measurements } \\
\end{array}$ & \multirow{5}{*}[22]{} \\
\hline & & & & & MRNIP & $66 \pm 3$ & Stable & \\
\hline & & & & & SDBS-RNIP & $36 / 220$ & $\begin{array}{c}\text { Bimodal size } \\
\text { distribution was } \\
\text { observed due to the } \\
\text { presence of SDBS } \\
\text { micelles } \\
\end{array}$ & \\
\hline & & & & & Polymer-RNIP 1 & $212 \pm 21$ & Stable & \\
\hline & & & & & Polymer-RNIP 2 & $178 \pm 11$ & Stable & \\
\hline
\end{tabular}




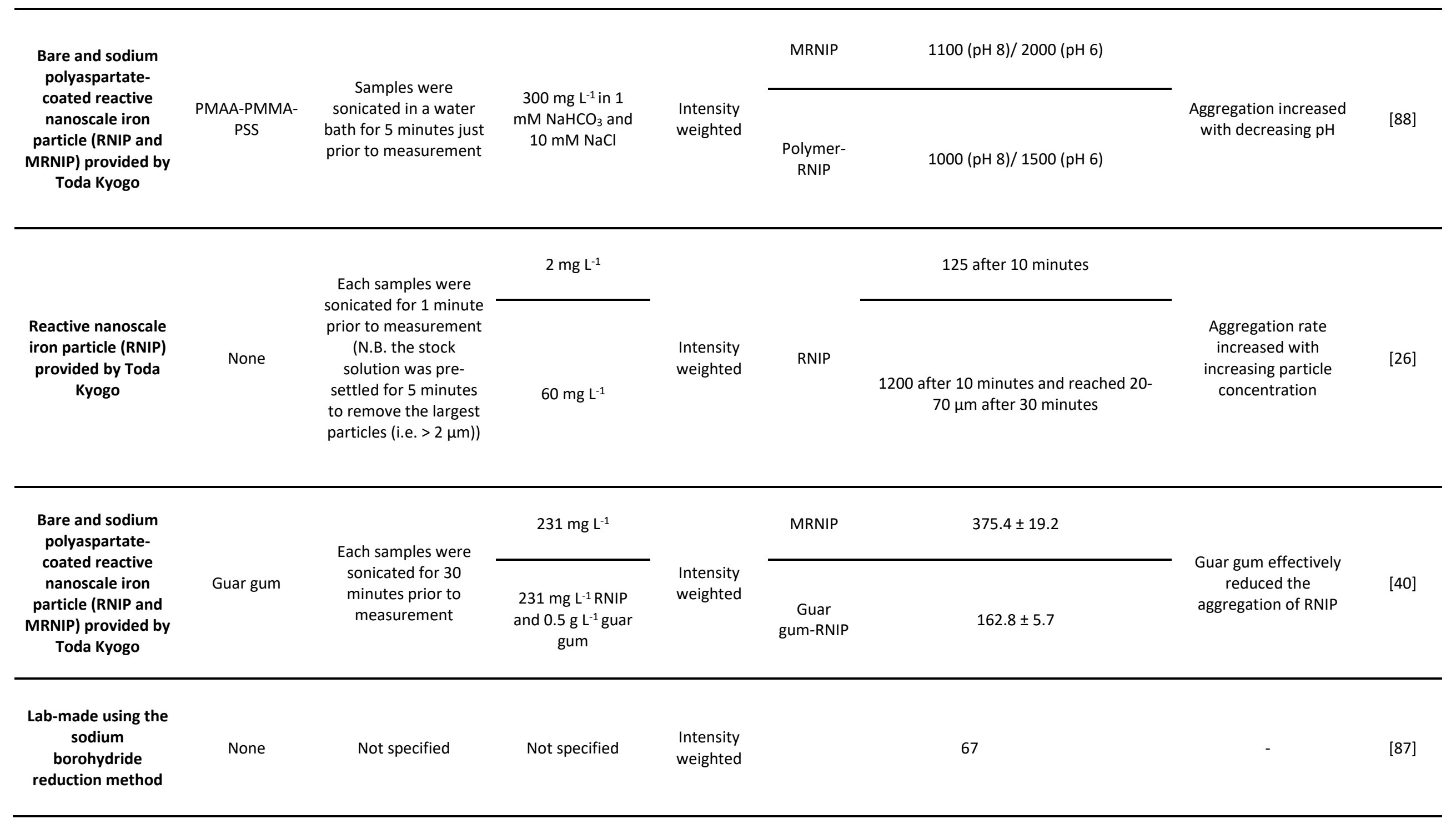




\begin{tabular}{|c|c|c|c|c|c|c|c|c|}
\hline \multirow{12}{*}{$\begin{array}{l}\text { Lab-made using the } \\
\text { sodium } \\
\text { borohydride } \\
\text { reduction method }\end{array}$} & \multirow{7}{*}{$\begin{array}{c}\text { Carboxymethyl } \\
\text { cellulose }(\mathrm{CMC}) \\
\text { at different } \\
\mathrm{CMC} / \mathrm{Fe}^{2+} \\
\text { molar ratio }\end{array}$} & \multirow{7}{*}{ Measured as prepared } & \multirow{4}{*}{$0.1 \mathrm{~g} \mathrm{~L}^{-1}$} & \multirow{4}{*}{$\begin{array}{c}\text { Volume } \\
\text { weighted }\end{array}$} & $\begin{array}{c}\mathrm{CMC} / \mathrm{Fe}^{2+}: \\
0.0062\end{array}$ & $>3 \mu \mathrm{m}(92.4 \%)$ & $\begin{array}{c}\text { Large aggregates } \\
\text { observed as the ratio } \\
\mathrm{CMC} / \mathrm{Fe}^{2+} \text { was too low } \\
\text { to stabilise the particles }\end{array}$ & \multirow{7}{*}[21]{} \\
\hline & & & & & $\begin{array}{l}\mathrm{CMC}^{-\mathrm{Fe}^{2+}}: \\
0.0124\end{array}$ & $\begin{array}{c}18.6(81 \%) / 161(5.1 \%) / 1460 \\
(13.9 \%)\end{array}$ & $\begin{array}{l}\text { Trimodal size } \\
\text { distribution }\end{array}$ & \\
\hline & & & & & $\begin{array}{c}\mathrm{CMC} / \mathrm{Fe}^{2+}: \\
0.0186\end{array}$ & $17.6(89.5 \%)$ & - & \\
\hline & & & & & $\begin{array}{c}\mathrm{CMC} / \mathrm{Fe}^{2+}: \\
0.0248\end{array}$ & $15.3(90.3 \%)$ & - & \\
\hline & & & \multirow{3}{*}{$1 \mathrm{~g} \mathrm{~L}^{-1}$} & \multirow{3}{*}{$\begin{array}{l}\text { Volume } \\
\text { weighted }\end{array}$} & $\begin{array}{c}\mathrm{CMC} / \mathrm{Fe}^{2+}: \\
0.0025\end{array}$ & $37.2(45 \%)$ & \multirow{3}{*}{$\begin{array}{c}\text { CMC is more effective } \\
\text { at higher iron } \\
\text { concentration as } \\
\text { nucleation of Fe atoms } \\
\text { is accelerated at } \\
\text { elevated reagent } \\
\text { concentrations (i.e. } \\
\mathrm{Fe}^{2+} \text { ) } \\
\end{array}$} & \\
\hline & & & & & $\begin{array}{c}\mathrm{CMC} / \mathrm{Fe}^{2+}: \\
0.0031\end{array}$ & $22.8(84 \%)$ & & \\
\hline & & & & & $\begin{array}{c}\mathrm{CMC} / \mathrm{Fe}^{2+}: \\
0.0050\end{array}$ & 19.6 (89.9\%) & & \\
\hline & $\begin{array}{c}\text { Carboxymethyl } \\
\text { cellulose (CMC) } \\
\text { used a } \\
\text { stabiliser to } \\
\text { prepare Fe-Pd } \\
\text { nanoparticles }\end{array}$ & Measured as prepared & $0.1 \mathrm{~g} \mathrm{~L}^{-1}$ & $\begin{array}{l}\text { Number } \\
\text { weighted }\end{array}$ & $\begin{array}{l}\text { CMC-stabilised } \\
\text { Fe-Pd } \\
\text { nanoparticles }\end{array}$ & $17.2 \pm 3.2$ & $\begin{array}{c}\text { Good agreement } \\
\text { observed among TEM } \\
\text { and DLS measurements }\end{array}$ & [43] \\
\hline & \multirow[t]{2}{*}{$\begin{array}{l}\text { Carboxymethyl } \\
\text { cellulose (CMC) }\end{array}$} & \multirow{2}{*}{$\begin{array}{l}\text { Samples were vortex } \\
\text { mixed for } 30 \text { seconds } \\
\text { prior to measurement }\end{array}$} & \multirow[t]{2}{*}{$150 \mathrm{mg} \mathrm{L}^{-1}$} & \multirow[t]{2}{*}{$\begin{array}{l}\text { Intensity } \\
\text { weighted }\end{array}$} & Bare nZVI & $\sim 400$ & - & \multirow[t]{2}{*}{ [89] } \\
\hline & & & & & CMC-nZVI & 135 & - & \\
\hline & \multirow{2}{*}{$\begin{array}{l}\text { Carboxymethyl } \\
\text { cellulose (CMC) }\end{array}$} & \multirow{2}{*}{ Measured as prepared } & $\begin{array}{c}0.1 \mathrm{~g} \mathrm{~L}^{-1}(0.2 \mathrm{wt} . \% \\
\mathrm{CMC})\end{array}$ & \multirow{2}{*}{$\begin{array}{l}\text { Intensity } \\
\text { weighted }\end{array}$} & $0.1 \mathrm{~g} \mathrm{~L}^{-1}$ & 61 to 123 (after $1 \mathrm{~h}$ ) & - & \multirow{2}{*}[90]{} \\
\hline & & & $\begin{array}{c}2.5 \mathrm{~g} \mathrm{~L}^{-1}(0.8 \mathrm{wt} . \% \\
\mathrm{CMC})\end{array}$ & & $2.5 \mathrm{~g} \mathrm{~L}^{-1}$ & 25 to 109 (after $1 \mathrm{~h}$ ) & - & \\
\hline
\end{tabular}


Table 2: Summary of different studies that have used XRD for nZVI characterisation.

\begin{tabular}{|c|c|c|c|c|}
\hline nZVI source & $\begin{array}{c}\text { Experimental } \\
\text { conditions/sample preparation }\end{array}$ & Fe-phases identified & Other observation & Ref. \\
\hline $\begin{array}{l}\text { Lab made } \mathrm{nZVI} \text { from } \mathrm{FeCl}_{3} \text { through } \\
\text { borohydride reduction }\end{array}$ & $\begin{array}{l}\text { nZVI particles }\left(2-5 \mathrm{~g} \mathrm{~L}^{-1}\right) \text { reacted } \\
\text { with an aqueous } \mathrm{As}(\mathrm{III}) \text { solution } \\
\text { (1.33 } \mathrm{mM}) \text { for } 24 \mathrm{~h} \text {; powder } \\
\text { diffraction in ambient air }\end{array}$ & $\mathrm{Fe}^{0}$ and ferrihydrite & $\begin{array}{l}\text { No significant change in core-shell } \\
\text { configuration due to reaction with As } \\
\text { (III); surface of nZVI particles was } \\
\text { decorated with loose debris of } \\
\text { ferrihydrite; grain size of } \mathrm{Fe}^{0} \text { core } 1 \mathrm{~nm}\end{array}$ & {$[64]$} \\
\hline $\begin{array}{l}\text { nZVI (RNIP-10DS) purchased from } \\
\text { Toda Kogyo Corp., Japan }\end{array}$ & 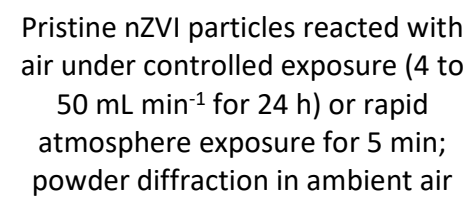 & $\begin{array}{l}\mathrm{Fe}^{0} \text {, magnetite }\left(\mathrm{Fe}_{3} \mathrm{O}_{4}\right) \text { and } \\
\text { maghemite }\left(\gamma-\mathrm{Fe}_{3} \mathrm{O}_{4}\right)\end{array}$ & $\begin{array}{l}\text { Intensities of the } \mathrm{Fe}^{0} \text { peaks for the } \\
\text { modified particles were weaker than } \\
\text { those for pristine } \mathrm{nZVI} \text { particles due to } \\
\text { transformation of } \mathrm{Fe}^{0} \text { to magnetite and } \\
\text { maghemite }\end{array}$ & {$[35]$} \\
\hline $\begin{array}{l}\text { Lab made } \mathrm{nZVI} \text { from } \mathrm{FeCl}_{3} \text { through } \\
\text { borohydride reduction }\end{array}$ & $\begin{array}{l}\text { nZVI particles synthesised under } \\
\text { aqueous ethanol conditions }(0,30, \\
70,90, \text { and } 100 \% \text { by volume); } \\
\text { powder diffraction in ambient air }\end{array}$ & $\begin{array}{l}\mathrm{Fe}^{0} \text {, iron oxides (magnetite and } \\
\text { maghemite) and iron hydroxides } \\
\text { (lepidocrocite, bernalite, } \\
\text { akaganéite, and goethite) }\end{array}$ & $\begin{array}{c}\text { Increasing ethanol concentrations } \\
\text { provided gradually decreasing particle } \\
\text { sizes ( } 20-50 \mathrm{~nm} \text { in no ethanol, } 10-30 \\
\mathrm{~nm} \text { in } 30 \% \text { ethanol, } 10-20 \mathrm{~nm} \text { in } 70 \% \\
\text { ethanol, } 5-20 \mathrm{~nm} \text { in } 90 \% \text { ethanol and } 2 \\
-5 \mathrm{~nm} \text { in } 100 \% \text { ethanol) and irregular } \\
\text { amorphous structure }\end{array}$ & [103] \\
\hline $\begin{array}{c}\text { nZVI purchased from } \\
\text { Nanostructured and Amorphous } \\
\text { Materials, Inc. (Houston, TX) }\end{array}$ & $\begin{array}{c}\text { nZVI reacted with dithionite }(0.2 \\
0.9,1.8 \text { and } 3.7 \mathrm{~g} \text { dithionite } \mathrm{g}^{-1} \text { of } \\
\mathrm{nZVI)} \text {; powder diffraction in } \\
\text { ambient air }\end{array}$ & $\mathrm{Fe}^{0}$, lepidocrocite and magnetite & $\begin{array}{l}\text { High dithionite concentration caused } \\
\text { green rust formation }\end{array}$ & [166] \\
\hline $\begin{array}{l}\text { Lab made } \mathrm{nZVI} \text { from } \mathrm{FeCl}_{3} \text { through } \\
\text { borohydride reduction }\end{array}$ & $\begin{array}{l}\text { nZVI synthesised in aqueous } \\
\text { ethanol solutions ( } 70 \text { or } 90 \% \\
\text { ethanol by volume); powder } \\
\text { diffraction in ambient air }\end{array}$ & $\mathrm{Fe}^{0}$ and iron oxides & $\begin{array}{l}\text { Appearance of broad } \alpha-\mathrm{Fe}^{0} \text { peak due to } \\
\text { short range order structure (amorphous) }\end{array}$ & [113] \\
\hline $\begin{array}{l}\text { Lab made } \mathrm{nZVI} \text { from } \mathrm{FeCl}_{3} \text { through } \\
\text { borohydride reduction }\end{array}$ & $\begin{array}{l}\left.\text { Surfactant (Tween }{ }^{\circledR} 80\right) \text { modified } \\
\text { nZVI }(2 \mathrm{mg}) \text { reacted with } \\
\text { trichloroethylene (TCE) }(20 \mathrm{~mL} \text { of } \\
\left.29 \mathrm{mg} \mathrm{L}^{-1}\right) ; \text { powder diffraction in } \\
\text { ambient air }\end{array}$ & $\mathrm{Fe}^{0}$ and $\gamma-\mathrm{Fe}_{2} \mathrm{O}_{3}$ & $\begin{array}{c}\text { Reaction with TCE caused disappearance } \\
\text { of } \mathrm{Fe}^{0} \text { peak and prominence of }{ }^{-}-\mathrm{Fe}_{2} \mathrm{O}_{3} \\
\text { peak }\end{array}$ & [121] \\
\hline
\end{tabular}




\begin{tabular}{|c|c|c|c|c|}
\hline $\begin{array}{l}\text { Lab made } \mathrm{nZVI} \text { from } \mathrm{FeCl}_{2} \text { through } \\
\text { borohydride reduction }\end{array}$ & $\begin{array}{c}\text { nZVI particles sprinkled } \\
\text { on to adhesive carbon tapes } \\
\text { supported on metallic disks }\end{array}$ & $\mathrm{Fe}^{0}, \mathrm{Fe}_{3} \mathrm{O}_{4}$ and $\nu-\mathrm{Fe}_{2} \mathrm{O}_{3}$ & $\begin{array}{c}\text { Fresh nZVI provided prominent } \mathrm{Fe}^{0} \text { peak, } \\
\text { oxide peaks dominated with ageing of } \\
\text { the sample }\end{array}$ & [120] \\
\hline $\begin{array}{l}\text { Lab made } \mathrm{nZVI} \text { from } \mathrm{FeCl}_{3} \text { through } \\
\text { borohydride reduction and } \\
\text { commercial nZVI product from } \\
\text { Kanto Chemical Co., Inc., Japan }\end{array}$ & $\begin{array}{c}\mathrm{nZVI}\left(50 \mathrm{~g} \mathrm{~L}^{-1}\right) \text { reacted with As (III) } \\
\left(100 \mathrm{mg} \mathrm{L}^{-1}\right) \text { in } 0.01 \mathrm{M} \mathrm{NaCl} \text { for } 1- \\
60 \text { days; powder diffraction in } \\
\text { ambient air }\end{array}$ & $\begin{array}{c}\mathrm{Fe}^{0}, \text { magnetite/maghemite } \\
\left(\mathrm{Fe}_{3} \mathrm{O}_{4} / \gamma-\mathrm{Fe}_{2} \mathrm{O}_{3}\right) \text {, lepidocrocite }(\gamma- \\
\mathrm{FeOOH})\end{array}$ & $\begin{array}{l}\text { Reactions provided a mixture of } \\
\text { amorphous Fe-oxide/hydroxide (Fe (II) } \\
\text { and Fe (III)) as the corrosion products of } \\
\text { nZVI; crystalline magnetite and } \\
\text { lepidocrocite replaced amorphous } \\
\text { phases over } 2 \text { months period }\end{array}$ & {$[53]$} \\
\hline $\begin{array}{c}\text { Lab made nZVI from } \mathrm{FeSO}_{4} \\
\text { through borohydride reduction } \\
\text { facilitated by dispersant } \\
\text { polyvinylpyrrolidone }\end{array}$ & Powder diffraction in ambient air & $\mathrm{Fe}^{0}$ & $\begin{array}{l}\text { Only evidence of } \mathrm{Fe}^{0} \text { formation shown; } \\
\text { broad } \mathrm{Fe}^{0} \text { peak appeared due to } \\
\text { amorphous structure }\end{array}$ & [117] \\
\hline $\begin{array}{l}\text { Lab made } \mathrm{nZVI} \text { from } \mathrm{FeSO}_{4} \\
\text { through borohydride reduction }\end{array}$ & $\begin{array}{c}\mathrm{nZVI}\left(20 \mathrm{~g} \mathrm{~L}^{-1}\right) \text { reacted with } \\
\text { trinitrotoluene (TNT) (around } 3 \mathrm{~g} \mathrm{~L}^{-} \\
\left.{ }^{1}\right) \text { for } 1 \mathrm{~h} \text {; powder diffraction in } \\
\text { ambient air }\end{array}$ & $\begin{array}{l}\mathrm{Fe}^{0} \text { and magnetite/maghemite } \\
\qquad\left(\mathrm{Fe}_{3} \mathrm{O}_{4} / \gamma-\mathrm{Fe}_{2} \mathrm{O}_{3}\right)\end{array}$ & $\begin{array}{l}\text { nZVI corrosion products consisted a } \\
\text { mixture of } \mathrm{Fe}_{3} \mathrm{O}_{4} \text { and } \gamma-\mathrm{Fe}_{2} \mathrm{O}_{3}\end{array}$ & [122] \\
\hline $\begin{array}{l}\text { nZVI purchased from Tianjin } \\
\text { Kermel Chemical Co., Ltd., China }\end{array}$ & $\begin{array}{c}\mathrm{nZVI}\left(3 \mathrm{~g} \mathrm{~L}^{-1}\right) \text { reacted with acid } \\
\left.\text { orange II (100 } \mathrm{mg} \mathrm{L}^{-1}\right) \text { at } \mathrm{pH} 3.0,7.0 \\
\text { and 11.0; powder diffraction in } \\
\text { ambient air }\end{array}$ & $\mathrm{Fe}^{0}$ and lepidocrocite & $\begin{array}{l}\text { Ferric hydroxides (lepidocrocite - } \\
\text { FeOOH) formed on the surface of the } \\
\text { reacted nZVI powder }\end{array}$ & [123] \\
\hline $\begin{array}{l}\text { Lab made } \mathrm{nZVI} \text { from } \mathrm{FeSO}_{4} \\
\text { through borohydride reduction }\end{array}$ & $\begin{array}{l}\text { nZVI stabilised with polyacrylic acid } \\
\text { and polyvinylpyrrolidone; powder } \\
\text { diffraction in ambient air }\end{array}$ & $\mathrm{Fe}^{0}, \mathrm{FeOOH}$ and $\mathrm{FeO}$ & $\begin{array}{l}\text { Polymer stabilised nZVI showed no iron } \\
\text { peak due to amorphous and non- } \\
\text { crystalline nature }\end{array}$ & [119] \\
\hline $\begin{array}{l}\text { nZVI (Nanofer } 25 \text { and Nanofer 25S) } \\
\text { purchased from NANOIRON }{ }^{\circledR} \\
\text { Company, Czech Republic, EU }\end{array}$ & $\begin{array}{c}\text { Nanofer } 25\left(150 \mathrm{mg} \mathrm{L}^{-1}\right) \text { reacted } \\
\text { with As }(\mathrm{V})\left(5 \mathrm{mg} \mathrm{L}^{-1}\right) \text { at } \mathrm{pH} 5 \text { and } 9 \\
\text { for } 90 \mathrm{~min} \text { and aged for } 30 \text { and } 60 \\
\text { days; powder diffraction in ambient } \\
\text { air after freeze drying }\end{array}$ & $\begin{array}{c}\mathrm{Fe}^{0} \text {, magnetite/maghemite, } \\
\text { lepidocrocite, hematite in Nanofer } \\
25 ; \text { not quantified; no obvious peak } \\
\text { for iron oxide appeared in the XRD } \\
\text { profile of Nanofer } 25 \mathrm{~S}\end{array}$ & $\begin{array}{l}\text { Hematite formed at } \mathrm{pH} 5 \text {, but not at } \mathrm{pH} \\
9 \text {; lepidocrocite and } \\
\text { magnetite/maghemite were the main } \\
\text { corrosion products after } 30 \text { days, } \\
\text { whereas lepidocrocite predominated } \\
\text { after } 60 \text { days }\end{array}$ & [167] \\
\hline $\begin{array}{l}\text { Lab made } \mathrm{nZVI} \text { from } \mathrm{FeCl}_{3} \text { through } \\
\text { borohydride reduction }\end{array}$ & $\begin{array}{l}\text { nZVI }\left(50 \mathrm{~g} \mathrm{~L}^{-1} \text { in } 0.01 \mathrm{M} \mathrm{NaCl}^{-1} \mathrm{pH}\right. \\
\text { 7) reacted } \mathrm{As}(\mathrm{V})\left(100 \mathrm{mg} \mathrm{L}^{-1}\right) \text { for } 7 \text {, } \\
\text { 30, } 60 \text { and } 90 \text { days; powder } \\
\text { diffraction in ambient air }\end{array}$ & $\begin{array}{l}\mathrm{Fe}^{0}, \text { magnetite/maghemite, } \\
\text { lepidocrocite }\end{array}$ & $\begin{array}{c}\text { Appearance of magnetite/maghemite } \\
\text { and lepidocrocite and appearance of } \\
\text { amorphous region in the expense of } \mathrm{Fe}^{0} \\
\text { peak after } 7 \text { days of ageing; sharp } \\
\text { crystalline peaks of lepidocrocite and } \\
\text { magnetite/ } \\
\text { maghemite appeared after } 30 \text { days; } \\
\text { lepidocrocite disappeared after } 60 \text { days } \\
\text { onwards }\end{array}$ & [68] \\
\hline
\end{tabular}




\begin{tabular}{|c|c|c|c|c|}
\hline $\begin{array}{l}\text { Lab made } \mathrm{nZVI} \text { from } \mathrm{FeCl}_{3} \text { through } \\
\text { borohydride reduction }\end{array}$ & $\begin{array}{c}\text { Surfactant (Tween 20) stabilised } \\
\text { nZVI; powder diffraction in ambient } \\
\text { air }\end{array}$ & $\mathrm{Fe}^{0} ;$ no other peak identified & $\begin{array}{l}\text { Surfactant stabilised nZVI showed peak } \\
\text { broadening due to surfactant artefact }\end{array}$ & [37] \\
\hline $\begin{array}{l}\text { Lab made nZVI by evaporation of } \\
\text { Fe in tungsten }(W) \text { boat at } 1773^{\circ} \mathrm{K} \\
\text { under He environment }(133 \mathrm{~Pa})\end{array}$ & $\begin{array}{l}\mathrm{nZVI} \text { treated under different } \\
\text { residual vacuum pressures } \\
\text { and temperatures; powder } \\
\text { diffraction in ambient air } \\
\end{array}$ & $\begin{array}{c}\mathrm{Fe}^{0}, y-\mathrm{Fe}_{2} \mathrm{O}_{3} \text { and/or } \\
\mathrm{Fe}_{3} \mathrm{O}_{4}\end{array}$ & $\begin{array}{l}\text { Presence of oxide species at the surface } \\
\text { of the passivated nanocrystalline } \\
\text { powders }\end{array}$ & [168] \\
\hline $\begin{array}{l}\text { Lab made } \mathrm{nZVI} \text { from } \mathrm{FeCl}_{3} \text { through } \\
\text { borohydride reduction }\end{array}$ & $\begin{array}{l}\text { Powder diffraction of ethanol } \\
\text { stored sample in ambient air }\end{array}$ & $\mathrm{Fe}^{0}$ and $\mathrm{FeO}$ & $\begin{array}{c}\text { Broad peak due to amorphous } \mathrm{Fe}^{0} \text { and } \\
\text { sharp peak due to crystalline } \mathrm{FeO} \\
\text { observed }\end{array}$ & {$[28]$} \\
\hline $\begin{array}{l}\text { Lab made } \mathrm{nZVI} \text { from } \mathrm{FeCl}_{2} \text { through } \\
\text { borohydride reduction }\end{array}$ & Powder diffraction in ambient air & $\mathrm{Fe}^{0}$, hematite and magnetite & $\begin{array}{c}\text { Freshly prepared sample showed only } \\
\mathrm{Fe}^{0} \text { peak; oxides peak appear after } 2 \\
\text { months of ageing; oxides could not be } \\
\text { quantified due to limitation of detection } \\
\text { limit } \\
\end{array}$ & [125] \\
\hline $\begin{array}{c}\text { Lab made } \mathrm{nZVI} \text { from } \mathrm{FeSO}_{4} \\
\text { through borohydride reduction } \\
\text { with ultrasound assistance }\end{array}$ & Powder diffraction in ambient air & $\mathrm{Fe}^{0}$ and $\mathrm{FeO}$ & $\begin{array}{l}\text { Ultrasound assisted synthesis provided } \\
\text { more crystallinity to } \mathrm{Fe}^{0}\end{array}$ & [118] \\
\hline $\begin{array}{l}\text { Lab made } \mathrm{nZVI} \text { from } \mathrm{FeCl}_{3} \text { through } \\
\text { borohydride reduction }\end{array}$ & Powder diffraction in ambient air & $\mathrm{Fe}^{0}$ & $\begin{array}{c}\text { Fresh nZVI with high reductive and } \\
\text { adsorptive activity has low crystallinity } \\
\text { of the metal phase and highly disordered } \\
\text { iron oxides }\end{array}$ & [169] \\
\hline
\end{tabular}


Table 3: Examples of studies that have used XPS and XAS for nZVI characterisation.

\begin{tabular}{|c|c|c|c|c|}
\hline nZVI source & $\begin{array}{c}\text { Sample storage/preparation } \\
\text { before measurement }\end{array}$ & Surface chemistry analysis & Other observation(s) & Ref. \\
\hline $\begin{array}{l}\text { Lab-made using the } \\
\text { sodium borohydride } \\
\text { reduction method }\end{array}$ & $\begin{array}{l}\text { After synthesis, sample was diluted } \\
\text { with ethanol to prevent particle } \\
\text { from oxidation. For XPS, the sample } \\
\text { was dried in a nitrogen-purged } \\
\text { hood at room temperature. Sample } \\
\text { preparation for XANES is not } \\
\text { specified }\end{array}$ & $\begin{array}{l}\text { XPS results showed no major changes } \\
\text { when sample was aged for } 24 \text { hours. The } \\
\text { surface of nZVI consisted of a layer of iron } \\
\text { oxides, likely in the FeO form and the } \\
\text { presence of Fe0 was also detected. } \\
\text { XANES results of aged particles (i.e. } 3 \\
\text { weeks) suggested that the material was } \\
\text { composed by } 44 \% \text { of Fe0 and } 56 \% \text { of FeO. } \\
\text { No Fe(III) was observed. }\end{array}$ & $\begin{array}{l}\text { Results from both XPS and XANES confirmed } \\
\text { the core-shell structure of nZVI. However, no } \\
\text { information on sample preparation for XANES } \\
\text { was provided. Besides, the results obtained } \\
\text { with the different instruments are not } \\
\text { comparable since the samples being analysed } \\
\text { were different (i.e. different sample } \\
\text { preparation, different sample age) }\end{array}$ & [28] \\
\hline $\begin{array}{l}\text { Reactive nanoscale iron } \\
\text { particle (RNIP) provided by } \\
\text { Toda Kyogo }\end{array}$ & $\begin{array}{l}\text { Shell-modified nZVI were prepared } \\
\text { by purging air to the particles at } \\
\text { different rates (i.e. } 4 \text { to } 50 \mathrm{~mL} \text { min- } \\
1 \text { for } 24 \mathrm{~h} \text { ) while rapidly oxidised } \\
\text { nZVI were exposed to the } \\
\text { atmosphere for } 5 \text { min. }\end{array}$ & $\begin{array}{l}\text { XPS results indicate that } \mathrm{Fe}_{3} \mathrm{O}_{4} \text { and } \mathrm{FeOOH} \\
\text { are the major shell components of the } \\
\text { "shell-modified nZVI". However, results for } \\
\text { the rapidly oxidised nZVI showed no peak } \\
\text { for FeOOH suggesting rapid oxidation } \\
\text { favours the formation of iron oxides rather } \\
\text { than iron oxyhydroxides. } \\
\text { XANES results confirmed XPS results and } \\
\text { showed more detailed composition of the } \\
\text { shell layer of rapidly oxidized nZVI (i.e. FeO; } \\
\qquad \mathrm{Fe}_{3} \mathrm{O}_{4} ; \alpha-\mathrm{Fe}_{2} \mathrm{O}_{3} ; \beta-\mathrm{Fe}_{2} \mathrm{O}_{3} \text { ). }\end{array}$ & $\begin{array}{c}\text { Shell-modified particles were quite resistant to } \\
\text { oxidation (upon exposure to atmosphere or } \\
\text { water) and showed very good performance for } \\
\text { the degradation of TCE (i.e. 78\% of those of } \\
\text { pristine nZVI) }\end{array}$ & [35] \\
\hline $\begin{array}{l}\text { Reactive nanoscale iron } \\
\text { particle (RNIP) provided by } \\
\text { Toda Kyogo ( } \mathrm{Fe}^{\mathrm{H} 2} \text { ) and lab- } \\
\text { made using the sodium } \\
\text { borohydride reduction } \\
\text { method }\left(\mathrm{Fe}^{\mathrm{BH}}\right)\end{array}$ & $\begin{array}{l}\text { Samples were prepared in an } \\
\text { anaerobic chamber and transferred } \\
\text { into the instrument without } \\
\text { exposure to air via a } \mathrm{N}_{2} \text {-purged } \\
\text { glovebag. }\end{array}$ & $\begin{array}{l}\text { XPS results showed that the } \mathrm{Fe}^{\mathrm{H} 2} \text { surfaces } \\
\text { were composed mainly of } \mathrm{Fe} \text { and } \mathrm{O}(\mathrm{Fe} / \mathrm{O} \\
\text { ratio of } 1.15 \text { ) with small amounts of } \mathrm{S}, \mathrm{Na} \\
\text { and } \mathrm{Ca} \text { while the surfaces of } \mathrm{Fe}^{\mathrm{BH}} \text { contained } \\
\text { less Fe and } \mathrm{S} \text { but more } \mathrm{B} \text { (from the } \\
\text { synthesis chemicals) and a lower } \mathrm{Fe} / \mathrm{O} \\
\text { ratio. }\end{array}$ & $\begin{array}{l}\text { The Fe } 2 p \text { XPS results showed } \mathrm{Fe} 0 \text { and iron } \\
\text { oxides peaks for both materials but the ratios } \\
\text { of } \mathrm{Fe}^{2+} \text { and } \mathrm{Fe}^{3+} \text { were not quantified. } \\
\text { Since XPS is sensitive to the outer } 3-5 \mathrm{~nm} \text { of } \\
\text { the nanoparticles, the Fe0 peak in the XPS } \\
\text { spectra confirmed that the shell thickness is } \\
\text { less than a few nanometers. }\end{array}$ & [14] \\
\hline
\end{tabular}




\begin{tabular}{|c|c|c|c|c|}
\hline $\begin{array}{l}\text { Reactive nanoscale iron } \\
\text { particle (RNIP) provided by } \\
\text { Toda Kyogo }\end{array}$ & $\begin{array}{l}\text { Samples were either analysed as- } \\
\text { received, exposed to DI water for } \\
24 \mathrm{~h} \text { or exposed to DI water } \\
\text { containing } 20 \mathrm{mg} \mathrm{L}-1 \text { natural } \\
\text { organic matter (NOM) for } 24 \mathrm{~h}\end{array}$ & $\begin{array}{l}\text { XPS results showed that the oxide shell of } \\
\text { the "as-received" nZVI was mainly } \\
\text { composed of Fe(III) while after exposure to } \\
\text { DI water and NOM, an Fe(II) component is } \\
\text { formed. Results also showed the presence } \\
\text { of } \mathrm{C} \text { and O in the surface of nZVI samples } \\
\text { exposed to NOM which increased the O to } \\
\text { Fe ratio. }\end{array}$ & $\begin{array}{l}\text { Authors indicated that it is possible to estimate } \\
\text { the thickness of a carbon overlayer on the } \\
\text { particles (i.e. due to the presence of NOM) } \\
\text { using two different approaches (put } \\
\text { references). }\end{array}$ & $\begin{array}{l}{[152,} \\
170]\end{array}$ \\
\hline $\begin{array}{l}\text { Lab-made using the } \\
\text { sodium borohydride } \\
\text { reduction method }\end{array}$ & $\begin{array}{l}\text { nZVI synthesised in aqueous } \\
\text { ethanol solutions ( } 70 \text { or } 90 \% \\
\text { ethanol by volume). After } \\
\text { synthesis, samples were washed } \\
\text { with ethanol solution to remove } \\
\text { any by-products from the synthesis } \\
\text { then centrifuged, freeze dried and } \\
\text { finally transferred to an anaerobic } \\
\text { chamber to be grounded into } \\
\text { powdered state before analysis. }\end{array}$ & $\begin{array}{l}\text { XPS results indicated that the oxide shell is } \\
\text { mainly composed of } \mathrm{Y} \text {-Fe2O3 or Fe3O4 (i.e. } \\
\text { feature peaks at } 531.0710 .9 \text { and } 724.4 \mathrm{eV} \text { ) } \\
\text { while a peak at around } 706.7 \mathrm{eV} \text { revealed } \\
\text { the presence of } \mathrm{Fe} 0 .\end{array}$ & $\begin{array}{l}\text { No further discussion on XPS results was } \\
\text { provided. }\end{array}$ & [171] \\
\hline $\begin{array}{l}\text { Lab-made using the } \\
\text { sodium borohydride } \\
\text { reduction method }\end{array}$ & $\begin{array}{l}\text { Fresh synthesised samples were } \\
\text { stored in } 95 \% \text { ethanol solution at } \\
\qquad 4^{\circ} \mathrm{C} \text { prior to use. }\end{array}$ & $\begin{array}{l}\text { XPS results indicated that } \mathrm{Hg}(\mathrm{II}) \text { was } \\
\text { sequestrated via chemical reduction to } \\
\text { elemental mercury. For } \mathrm{Zn}(\mathrm{II}) \text {, the removal } \\
\text { by } \mathrm{nZVI} \text { was achieved via sorption to the } \\
\text { iron oxide shell followed by zinc hydroxide } \\
\text { precipitation. Finally, hydrogen sulfide was } \\
\text { immobilized on the surface of nZVI (i.e. } \\
\text { oxide shell) as disulfide }\left(\mathrm{S}_{2}^{2-}\right) \text { and } \\
\text { monosulfide }\left(\mathrm{S}^{2-}\right) \text { species. }\end{array}$ & $\begin{array}{l}\text { XPS results highlighted the various reactive } \\
\text { pathways (i.e. reduction, sorption, surface } \\
\text { mineralization) between nZVI (i.e. Fe0 core and } \\
\text { iron oxide shell) and targeted contaminants } \\
\text { demonstrating the multiple functional } \\
\text { properties of nZVI. }\end{array}$ & [38] \\
\hline
\end{tabular}




\begin{tabular}{|c|c|c|c|c|}
\hline $\begin{array}{l}\text { Lab-made using the } \\
\text { sodium borohydride } \\
\text { reduction method }\end{array}$ & $\begin{array}{l}\text { Fresh synthesised samples were } \\
\text { exposed to oxygen and water for } \\
72 \mathrm{~h} \text { prior to analysis. }\end{array}$ & $\begin{array}{l}\text { XPS results showed that the surface of the } \\
72 \mathrm{~h} \text { exposed nZVI was mainly composed of } \\
\text { iron oxides and hydroxides. A peak at } 711 \\
\mathrm{eV} \text { revealed the presence of } \mathrm{Fe}_{2} \mathrm{O}_{3}, \mathrm{Fe}_{3} \mathrm{O}_{4} \\
\mathrm{Fe}(\mathrm{OH})_{3} \text { or FeOOH while a peak at } 725 \mathrm{eV} \\
\text { suggested the presence of ferric oxides } \\
\text { (Fe(III)). Further analysis (i.e. O } 1 \mathrm{~s} \text { survey } \\
\text { scans) revealed that FeOOH was the main } \\
\text { component of oxidised nZVI. }\end{array}$ & $\begin{array}{l}\text { The combination of XRD, XPS and Raman } \\
\text { spectra analysis allowed the accurate } \\
\text { determination of the final corrosion products } \\
\text { of oxidised nZVI. }\end{array}$ & [172] \\
\hline $\begin{array}{l}\text { Lab-made using the } \\
\text { sodium borohydride } \\
\text { reduction method }\end{array}$ & $\begin{array}{c}\text { nZVI was exposed to an anoxic } \\
\text { As(III) solution (i.e. } 1.33 \mathrm{mM} \text { ) for } 22 \\
\text { h before analysis. }\end{array}$ & $\begin{array}{l}\text { Time-dependent in-situ XAS analysis of the } \\
\text { arsenic core level showed that As(III) } \\
\text { species go through two distinct } \\
\text { transformation stages after adsorption on } \\
\text { the nZVI oxide shell surface: (1) Breaking of } \\
\text { the As-O bonds at the particle surface and } \\
\text { (2) Reduction to elemental As and diffusion } \\
\text { across the oxide layer to form an } \\
\text { intermetallic phase with the FeO core. }\end{array}$ & $\begin{array}{c}\text { Extended EXAFS analysis (i.e. performed at } \\
\text { different Fe/As ratio) revealed an } \\
\text { accumulation of partially reduced arsenic at } \\
\text { the core/shell interface at large arsenic } \\
\text { content. }\end{array}$ & [64] \\
\hline $\begin{array}{l}\text { Reactive nanoscale iron } \\
\text { particle (RNIP) provided by } \\
\text { Toda Kyogo }\end{array}$ & $\begin{array}{l}\text { nZVI was aged in synthetic } \\
\text { groundwater (i.e. exposed to } \\
\text { common groundwater anions or to } \\
\text { dissolved oxygen) over } 6 \text { months } \\
\text { prior to analysis. }\end{array}$ & $\begin{array}{l}\text { XANES and EXAFS results showed that after } \\
1 \text { month, the different anions inhibited the } \\
\text { oxidation of nZVI to varying degrees while } \\
\text { after } 6 \text { months aging, the oxidation states } \\
\text { of nZVI exposed to different anions were } \\
\text { very similar except for nitrate which was } \\
\text { able to completely inhibit the oxidation of } \\
\text { nZVI, even after } 6 \text { months. However, nZVI } \\
\text { exposed to water saturated with dissolved } \\
\text { oxygen showed a rapid loss of Fe } 0 \text { within } \\
24 \text { h of exposure. }\end{array}$ & $\begin{array}{l}\text { Linear least-squares combination fitting of the } \\
\text { EXAFS spectra indicated that, after } 1 \text { month, } \\
\text { the system was mainly composed of } \mathrm{Fe} 0 \text { and } \\
\mathrm{Fe}_{3} \mathrm{O}_{4} \text { while after } 6 \text { months, additional species } \\
\text { (i.e. which depends on the anions to which } \\
\mathrm{nZVI} \text { was exposed) such as vivianite and iron } \\
\text { sulfate species were identified. Results for the } \\
\mathrm{nZVI} \text { exposed to dissolved oxygen showed the } \\
\text { presence of magnetite and maghemite within } \\
\text { the oxide layer. }\end{array}$ & [109] \\
\hline
\end{tabular}


Table 4: Physical and chemical properties of commercial ZVI products as reported by the manufacturers.

\begin{tabular}{ccccccccc}
\hline N\# & Form & Colour & $\begin{array}{c}\text { Fe } \\
\text { content } \\
\mathbf{( \% )}\end{array}$ & $\begin{array}{c}\text { Solid } \\
\text { content (\%) }\end{array}$ & $\begin{array}{c}\text { Melting } \\
\left.\text { Point } \mathbf{(}^{\circ} \mathbf{C}\right)\end{array}$ & $\begin{array}{c}\text { Density } \\
\left(\mathbf{g ~ c m}^{-3}\right)\end{array}$ & $\begin{array}{c}\text { Particle Size } \\
(\boldsymbol{\mu} \mathbf{m})\end{array}$ & $\begin{array}{c}\text { Sold as } \\
\mathbf{n Z V I}\end{array}$ \\
\hline P1 & Powder & Black & 98 & 100 & 1536 & 7.87 & $0.1-0.25$ & Yes \\
P2 & Powder & Dark grey & 95.5 & 100 & 1536 & 7.8 & $70-80$ & No \\
P3 & Powder & Dark grey & 99 & 100 & 1536 & 7.87 & $5-50$ & No \\
S1 & Slurry & Black & 20 & 20 & N/A & $1.15-1.25$ & $<0.1$ & Yes \\
S2 & Slurry & Black & 20 & 20 & N/A & $1.15-1.25$ & $<0.1$ & Yes \\
\hline
\end{tabular}

Table 5: Iron content of the 5 commercial nZVI/ZVI products: Comparison between the manufacturers' data and XRD analysis.

\begin{tabular}{llccc}
\hline \multirow{2}{*}{$\begin{array}{c}\text { Commercial } \\
\text { nZVI }\end{array}$} & Form & $\begin{array}{c}\text { Fe(0) as per } \\
\text { manufacturer }\end{array}$ & Zero-valent Iron & \begin{tabular}{c} 
Iron content analysed using XRD \\
\cline { 3 - 4 }
\end{tabular} \\
\cline { 4 - 5 } & & 98 & 92 & $\begin{array}{c}\text { Iron } \\
\text { (Fe(II), Fe (III)) }\end{array}$ \\
\hline P1 & Powder & 95.5 & 47 & 8 \\
P2 & Powder & 99 & 34 & 53 \\
P3 & Powder & 100 & 98 & 66 \\
S1 & Slurry & 100 & 91 & 2 \\
S2 & Slurry & & & 9 \\
\hline
\end{tabular}

Table 6: Linear combination fitting of the XAS data for the 5 commercial nZVI/ZVI products tested. Species proportions are presented as percentages. Goodness of fit is indicated by the $\chi^{2}$ value.

\begin{tabular}{lcccccc}
\hline $\begin{array}{c}\text { Commercial } \\
\text { nZVI }\end{array}$ & Fe(0) & Magnetite & Maghemite & Lepidocrocite & Wuestite & $\boldsymbol{\chi}^{2}$ \\
\hline P1 & 79 & 12 & & 9 & 0.0001 \\
P2 & 49 & 15 & 36 & & 0.0005 \\
P3 & 24 & 28 & 8 & & 0.0040 \\
S1 & 85 & 15 & & & 0.0001 \\
S2 & 76 & 8 & 8 & 8 & & 0.0001 \\
\hline
\end{tabular}


Table 7: Coordination parameters of Fe in the samples.

\begin{tabular}{|c|c|c|c|c|c|c|}
\hline Sample & $\begin{array}{c}\text { Energy shift } \\
\text { DE (eV) }\end{array}$ & Shell & $\begin{array}{c}\text { Coordination } \\
\text { Number } \\
\text { CN }\end{array}$ & $\begin{array}{c}\text { Interatomic bond } \\
\text { distance } \\
\mathbf{R}(\AA)\end{array}$ & $\begin{array}{c}\text { Debye-Waller } \\
\text { factor } \\
s^{2}\end{array}$ & $\begin{array}{l}\text { Error } \\
\mathbf{R}^{2}\end{array}$ \\
\hline \multirow[t]{4}{*}{ P1 } & 2.87 & $\mathrm{Fe}-\mathrm{Fe}_{1}$ & 8 & 2.49 & 0.007 & 4.26 \\
\hline & & $\mathrm{Fe}-\mathrm{Fe}_{2}$ & 6 & 2.84 & 0.012 & \\
\hline & & $\mathrm{Fe}-\mathrm{Fe}_{3}$ & 12 & 4.10 & 0.011 & \\
\hline & & $\mathrm{Fe}^{-\mathrm{Fe}_{4}}$ & 24 & 4.79 & 0.007 & \\
\hline \multirow[t]{6}{*}{$\mathrm{P} 2$} & 1.19 & $\mathrm{Fe}_{\| I I}-\mathrm{O}_{1}$ & 6 & 1.94 & 0.013 & 4.75 \\
\hline & & $\mathrm{Fe}-\mathrm{Fe}_{1}$ & 8 & 2.55 & 0.015 & \\
\hline & & $\mathrm{Fe}-\mathrm{Fe}_{2}$ Metal & 6 & 2.79 & 0.002 & \\
\hline & & $\mathrm{Fe}-\mathrm{Fe}_{2}$ Oxide & 6 & 2.94 & 0.003 & \\
\hline & & $\mathrm{Fe}-\mathrm{Fe}_{3}$ & 12 & 4.04 & 0.013 & \\
\hline & & $\mathrm{Fe}^{-\mathrm{Fe}_{4}}$ & 24 & 4.73 & 0.017 & \\
\hline \multirow[t]{7}{*}{ P3 } & 1.44 & $\mathrm{Fe}_{\| I}-\mathrm{O}_{1}$ & 6 & 1.97 & 0.018 & 5.76 \\
\hline & & $\mathrm{Fe}_{\|}-\mathrm{O}_{1}$ & 6 & 2.19 & 0.002 & \\
\hline & & $\mathrm{Fe}-\mathrm{Fe}_{1}$ & 8 & 2.51 & 0.015 & \\
\hline & & $\mathrm{Fe}-\mathrm{Fe}_{2}$ Metal & 6 & 2.72 & 0.016 & \\
\hline & & $\mathrm{Fe}-\mathrm{Fe}_{2}$ Oxide & 6 & 3.32 & 0.021 & \\
\hline & & $\mathrm{Fe}-\mathrm{Fe}_{3}$ & 12 & 3.99 & 0.020 & \\
\hline & & $\mathrm{Fe}-\mathrm{Fe}_{4}$ & 24 & 4.83 & 0.030 & \\
\hline \multirow[t]{4}{*}{ S1 } & 1.91 & $\mathrm{Fe}-\mathrm{Fe}_{1}$ & 8 & 2.49 & 0.006 & 5.47 \\
\hline & & $\mathrm{Fe}-\mathrm{Fe}_{2}$ & 6 & 2.83 & 0.010 & \\
\hline & & $\mathrm{Fe}-\mathrm{Fe}_{3}$ & 12 & 4.10 & 0.010 & \\
\hline & & $\mathrm{Fe}-\mathrm{Fe}_{4}$ & 24 & 4.77 & 0.007 & \\
\hline \multirow[t]{4}{*}{ S2 } & 2.02 & $\mathrm{Fe}-\mathrm{Fe}_{1}$ & 8 & 2.49 & 0.006 & 4.16 \\
\hline & & $\mathrm{Fe}-\mathrm{Fe}_{2}$ & 6 & 2.84 & 0.012 & \\
\hline & & $\mathrm{Fe}-\mathrm{Fe}_{3}$ & 12 & 4.10 & 0.011 & \\
\hline & & $\mathrm{Fe}_{-} \mathrm{Fe}_{4}$ & 24 & 4.78 & 0.007 & \\
\hline \multirow[t]{4}{*}{ Fe Metal } & 1.02 & $\mathrm{Fe}-\mathrm{Fe}_{1}$ & 8 & 2.49 & 0.003 & 2.37 \\
\hline & & $\mathrm{Fe}-\mathrm{Fe}_{2}$ & 6 & 2.87 & 0.004 & \\
\hline & & $\mathrm{Fe}-\mathrm{Fe}_{3}$ & 12 & 4.06 & 0.005 & \\
\hline & & $\mathrm{Fe}-\mathrm{Fe}_{4}$ & 24 & 4.76 & 0.005 & \\
\hline
\end{tabular}


Table 8: Examples of characterisation studies investigating the behaviour of $\mathrm{nZVI}$ in different aqueous media.

\begin{tabular}{|c|c|c|c|c|c|}
\hline nZVI source & $\begin{array}{c}\mathrm{nZVI} \\
\text { concentration }\end{array}$ & Environmental media & Analytical methods & Observation(s) & Ref. \\
\hline $\begin{array}{l}\text { One lab-made } \mathrm{nZVI} \text { using } \\
\text { the sodium borohydride } \\
\text { reduction method and } 2 \\
\text { commercial nZVI provided by } \\
\text { NANOIRON Ltd. (NANOFER } \\
25 \text { and 25S) }\end{array}$ & $150 \mathrm{mg} \mathrm{L}^{-1}$ & $\begin{array}{l}\text { pH 8.5, 1-50 mg NaCl L-1 for } \\
\text { aggregation study; Synthetic } \\
\text { groundwater with different } \\
\text { concentration of humic acid } \\
\text { for As/Cr desorption study }\end{array}$ & $\begin{array}{l}\text { Laser Light Scattering (LLS) } \\
\text { for aggregation study; } \\
\text { Atomic Absorption } \\
\text { Spectroscopy (AAS) for } \\
\text { desorption study }\end{array}$ & $\begin{array}{l}\text { Slight variations in particle size with increased ionic strength. } \\
\text { Authors explained that the size measured by LLS is the size of the } \\
\text { particles remaining in suspension (i.e. first measurement was only } \\
\text { taken after } 30 \text { minutes) (rest of the particles sedimented in the } \\
\text { cuvette). No information on the sedimented particles were } \\
\text { provided (e.g. mass fraction). nZVI was found to deposit faster in } \\
\text { the presence of Cr and As which was attributed to the precipitation } \\
\text { of Cr/As onto the nZVI surface. Desorption of both Cr and As was } \\
\text { observed in the presence of typical groundwater conditions and } \\
\text { was more pronounced for As. }\end{array}$ & [155] \\
\hline $\begin{array}{l}\text { Bare and guar gum-coated } \\
\text { reactive nanoscale iron } \\
\text { particle (RNIP) (Bare RNIP } \\
\text { were provided by Toda } \\
\text { Kyogo) }\end{array}$ & $\begin{array}{l}150 \mathrm{mg} \mathrm{L}^{-1} \text { for } \\
\text { aggregation } \\
\text { study and } 385 \\
\quad \mathrm{mg} \mathrm{L}^{-1} \text { for } \\
\text { sedimentation } \\
\quad \text { study }\end{array}$ & $\begin{array}{l}\mathrm{pH} \mathrm{7.0,} 10 \mathrm{mM} \mathrm{NaCl}, 0.5 \mathrm{M} \\
\mathrm{NaCl} \text { and } 3 \mathrm{mM} \mathrm{CaCl} \\
\text { for } \\
\text { aggregation study; } \mathrm{pH} \mathrm{7.0,} \\
100 \mathrm{mM} \mathrm{NaCl} \text { and } 3 \mathrm{mM} \\
\mathrm{CaCl}_{2} \text { for sedimentation } \\
\text { study }\end{array}$ & $\begin{array}{l}\text { Dynamic light scattering } \\
\text { (DLS) for aggregation study; } \\
\text { UV-vis spectrophotometer } \\
\text { for sedimentation study }\end{array}$ & $\begin{array}{l}\text { During aggregation study, sedimentation of the larger aggregates } \\
\text { (sedimentation rate of } 0.27 \mathrm{~mm} \mathrm{~min}^{-1} \text { calculated by the authors) } \\
\text { likely affected the DLS measurement. Results from DLS and UV-vis } \\
\text { measurements are not comparable since different concentrations } \\
\text { were used. The electrolyte concentrations tested in this study were } \\
\text { much higher than the ones found in groundwater. }\end{array}$ & [40] \\
\hline $\begin{array}{l}\text { NANOFER 25S (PAA-coated } \\
\text { nZVI) from NANOIRON Ltd. } \\
\text { and Starch and Tween } 20 \\
\text { coated nZVIs prepared in lab } \\
\text { from commercial nZVI } \\
\text { NANOFER } 25 \text { (NANOIRON } \\
\text { Ltd) }\end{array}$ & $100 \mathrm{mg} \mathrm{L}^{-1}$ & $\begin{array}{l}\text { 0-20 mg HA L-1 for } \\
\text { aggregation study; } 0-10 \mathrm{mg} \\
\mathrm{HA} \mathrm{L}^{-1} \text { for sedimentation } \\
\text { study }\end{array}$ & $\begin{array}{l}\text { DLS for aggregation study; } \\
\text { UV-vis spectrophotometer } \\
\text { for sedimentation study }\end{array}$ & $\begin{array}{l}\text { Both aggregation and sedimentation studies showed enhanced } \\
\text { stability of nZVI at higher HA concentration. A two-phase } \\
\text { aggregation/sedimentation regime was observed with rapid } \\
\text { sedimentation of large aggregates in the first few minutes followed } \\
\text { by slow aggregation/sedimentation with time of the remaining } \\
\text { particles in suspension. }\end{array}$ & [150] \\
\hline $\begin{array}{l}\text { NANOFER STAR, NANOFER } \\
25 S \text { and NANOFER } 25 S S \\
\text { provided by NANOIRON Ltd. }\end{array}$ & $3 \mathrm{~g} \mathrm{~L}^{-1}$ & $\begin{array}{l}\text { The three commercial } \\
\text { products were aged for } 28 \\
\text { days in } \mathrm{NanoPure}^{2} \text { water, } 10 \\
\mathrm{mM} \mathrm{CaCl}, \mathbf{1 0 0} \mathrm{mM} \mathrm{CaCl}_{2} \\
\text { and one groundwater } \\
\text { sample under both } \\
\text { anaerobic and aerobic } \\
\text { conditions for each media }\end{array}$ & $\begin{array}{l}\text { Inductively coupled } \\
\text { plasma atomic emission } \\
\text { spectroscopy (ICP-AES) for } \\
\text { total iron concentration; } \\
\text { DLS for particle size; } \\
\text { Colorimeter to determine } \\
\text { the ferrous ion } \\
\text { concentration; Oxidation- } \\
\text { Reduction potential (ORP) } \\
\text { measured with a portable } \\
\text { meter }\end{array}$ & $\begin{array}{l}\text { A decrease in particles/aggregates size was observed in the } \\
\text { supernatant over time. DLS only measured the smaller particles } \\
\text { remaining in suspension while the larger aggregates quickly } \\
\text { sedimented in the measurement cell. Reduction in particle size was } \\
\text { also explained by the rapid oxidation of nZVI particles. } \\
\text { Particles/Aggregates size as large as } 7 \mu \mathrm{m} \text { was reported in this } \\
\text { study which is far beyond the limit of detection of DLS (i.e. } 5 \mu \mathrm{m} \text { ). }\end{array}$ & [156] \\
\hline
\end{tabular}




\begin{tabular}{|c|c|c|c|c|c|}
\hline $\begin{array}{l}\text { Commercial nZVI powder } \\
\text { provided by Nanostructured } \\
\text { and Amorphous Materials, } \\
\text { Inc. }\end{array}$ & $2 \mathrm{~g} \mathrm{~L}^{-1}$ & $\begin{array}{l}\text { nZVI suspensions were aged } \\
\text { for } 1 \text { month in } 5,25 \text { and } 100 \\
\mathrm{mN} \mathrm{Cl}, \mathrm{SO}_{4}^{2}-\text { and } \mathrm{ClO}_{4}^{-} \text {and } \\
\text { in } 5 \text { and } 25{\mathrm{mN} \mathrm{HCO}_{3}^{-} \text {and }}^{\mathrm{NO}_{3}^{-}}\end{array}$ & $\begin{array}{l}\text { X-ray diffraction (XRD) and } \\
\text { Transmission electron } \\
\text { microscopy (TEM) for } \\
\text { mineralogy study }\end{array}$ & $\begin{array}{l}\text { Both XRD and TEM results confirmed the development of corrosion } \\
\text { products in aged samples with the formation of magnetite, } \\
\text { carbonate green rust and iron carbonate hydroxide which resulted } \\
\text { in decreasing the reactivity of nZVI toward different contaminants. }\end{array}$ & [154] \\
\hline $\begin{array}{l}\text { Lab-made CMC-nZVI using } \\
\text { the sodium borohydride } \\
\text { reduction method }\end{array}$ & $200 \mathrm{mg} \mathrm{L}^{-1}$ & $\begin{array}{l}0.1 \mathrm{mM} \text { and } 10 \mathrm{mM} \mathrm{NaHCO} \\
\text { for transport and deposition } \\
\text { study }\end{array}$ & $\begin{array}{l}\text { AAS for Fe concentration in } \\
\text { the effluent samples }\end{array}$ & Increased ionic strength enhanced particle deposition of CMC-nZVI. & [153] \\
\hline $\begin{array}{l}\text { Lab-made PVP and PAA } \\
\text { stabilised nZVI using the } \\
\text { sodium borohydride } \\
\text { reduction method }\end{array}$ & $200 \mathrm{mg} \mathrm{L}^{-1}$ & $\begin{array}{c}\mathrm{pH} 7.5 ; 1,10 \text { and } 100 \mathrm{mM} \\
\mathrm{NaCl}\end{array}$ & $\begin{array}{l}\text { Scanning Electron } \\
\text { Microscope (SEM) and } \\
\text { Energy Dispersive X-Ray } \\
\text { Spectrometer (EDS) to } \\
\text { determine the deposition } \\
\text { mechanism of nZVI and } \\
\text { AAS for Fe concentration in } \\
\text { the effluent samples }\end{array}$ & $\begin{array}{l}\text { Increased ionic strength enhanced aggregation and particle } \\
\text { deposition of both polymer stabilised nZVI. SEM-EDS results } \\
\text { confirmed the attachment of nZVI aggregates onto the sand grains. }\end{array}$ & [151] \\
\hline $\begin{array}{l}\text { Lab-made } P d / n Z V I \text { using the } \\
\text { sodium borohydride } \\
\text { reduction method }\end{array}$ & $\begin{array}{l}1.7 \mathrm{~kg} \text { injected } \\
\text { over a } 2 \text {-day } \\
\text { period }\end{array}$ & $\begin{array}{l}\text { Real field scale study in a } \\
\text { TCE-contaminated site } \\
\text { (Trenton, New Jersey) }\end{array}$ & $\begin{array}{l}\text { ORP and } \mathrm{pH} \text { measured on } \\
\text { site with a portable meter; } \\
\text { Certified analytical } \\
\text { laboratory using US EPA } \\
\text { standard protocols for } \\
\text { total and dissolved iron, } \\
\text { TCE and its daughter } \\
\text { compounds concentration }\end{array}$ & $\begin{array}{l}\text { The TCE reduction observed on site correlated well with the change } \\
\text { in ORP at the monitoring location close to the injection well. The } \\
\text { correlation was less obvious for the monitoring points located } \\
\text { further where a lag period of one to several days was observed } \\
\text { between the ORP and TCE decline. }\end{array}$ & [3] \\
\hline $\begin{array}{l}\text { Lab-made CMC-nZVI using } \\
\text { the sodium borohydride } \\
\text { reduction method }\end{array}$ & $900 \mathrm{mg} \mathrm{Fe} \mathrm{L^{-1 }}$ & $\begin{array}{l}\text { Field-scale study in a model } \\
\text { aquifer }\end{array}$ & $\begin{array}{l}\text { Multi-method approach to } \\
\text { monitor the total and } \\
\text { dissolved iron, dissolved } \\
\text { oxygen (DO), specific } \\
\text { conductance, pH, ORP }\end{array}$ & $\begin{array}{l}\text { Total unoxidized nZVI was only transported in the first meter and } \\
\text { less than } 2 \% \text { of the total injected } n Z V I \text { reached this distance. } \\
\text { Conventional indicators used in field scale studies such as DO, ORP } \\
\text { and pH may not necessarily measure the presence of nZVI. }\end{array}$ & [162] \\
\hline $\begin{array}{l}\text { On-site synthesis of CMC- } \\
\text { nZVI using the sodium } \\
\text { borohydride reduction } \\
\text { method }\end{array}$ & $1 \mathrm{~g} \mathrm{~L}^{-1}$ & $\begin{array}{l}\text { Real field-scale study } \\
\quad \text { (Sarnia, Ontario) }\end{array}$ & $\begin{array}{l}\text { Inductively coupled } \\
\text { plasma-optical emission } \\
\text { spectroscopy (ICP-OES) for } \\
\text { total iron concentration; } \\
\text { TEM and EDS to } \\
\text { characterise the change in } \\
\text { nZVI before and after } \\
\text { injection }\end{array}$ & $\begin{array}{l}\text { After } 10 \text { days, only } 1 \% \text { of the total injected nZVI was detected from } \\
\text { the monitoring well ( } 1 \mathrm{~m} \text { from injection well) which most likely } \\
\text { indicated the deposition of particles on the subsurface porous } \\
\text { medium. Measurements of total iron concentration after } 48 \mathrm{~h} \text { is } \\
\text { believed to be related to dissolved iron in low concentration rather } \\
\text { than mobile iron nanoparticles. TEM-EDS measurements showed } \\
\text { no morphological changes between the injected particles and the } \\
\text { ones recovered from the monitoring well. }\end{array}$ & [161] \\
\hline
\end{tabular}




\section{List of Figure captions:}

Figure 1: The core-shell model of zero-valent iron nanoparticles (adapted from [16]). The core is made of metallic iron while the shell consists mostly of iron oxides and hydroxides. Thus ZVI nanoparticles exhibit characteristics of both iron oxides (e.g., as a sorbent) and metallic iron (e.g., as a reductant).

Figure 2: Bright-field TEM images of a) a single $n Z V I, b)$ an aggregate of $n Z V I$ and c) TEM image showing the oxide layer at the surface of an nZVI. [a) and b): Reprinted with permission from ref. [28] Copyright 2006 Elsevier; c): Reprinted with permission from ref. [62], Copyright 2008 American Chemical Society]

Figure 3: Top: High-angle annular dark field (HAADF) images of a) fresh ZVI nanoparticle and b) fresh $\mathrm{Fe} / \mathrm{Pd}$ bimetallic nanoparticle; Bottom: Corresponding TEM-XEDS intensity map of a) $\mathrm{Fe}$, b) $\mathrm{O}$ and c) $\mathrm{Pd}$ in fresh $\mathrm{Fe} / \mathrm{Pd}$ bimetallic nanoparticles; d) a false colour image of the three components overlayed. [Reprinted with permission from ref. [63] Copyright 2010 American Chemical Society]

Figure 4: Examples of SEM images of a commercialised sample of $\mathrm{ZVI}$ at $\mathrm{pH}$ 2: a microparticle imaged in a) SE mode clearly showing the surface features, b) imaged in BSE mode showing less contrast in the core, $c$ ) an overlay of SE and BSE, suggestive of a lower density surface layer such as a stabiliser or an oxide layer; d) aggregated nZVI sample; e) nZVI particles isolated for size determination by adsorbing them onto a poly-L-lysine coated graphite substrate. (FEI Quanta 450 ESEM with FEG source under high vacuum; a) -c) HV = 20 kV, d) HV = $15 \mathrm{kV}$, e) HV = 30 kV; WD = 5-10 mm).

Figure 5: Simulated sub-surface trajectories (that collectively map the interaction volume) of 100 electrons from a $10 \mathrm{~nm}$ beam of a) $20 \mathrm{kV}$ on Fe, b) $5 \mathrm{kV}$ on Fe $\mathrm{O}_{3}$, and c) $20 \mathrm{kV}$ on $\mathrm{Fe}_{2} \mathrm{O}_{3}$ (Monte Carlo simulations performed using the CASINO program [173]).

Figure 6: Examples of SEM images of commercialised ZVI samples at pH 2.

Figure 7: XRD patterns of commercial ZVI/nZVI particles. Numbers indicate characteristic iron phase peaks as follows; $1=\mathrm{ZVI}(\mathrm{Fe}), 2=$ magnetite $\left(\mathrm{Fe}_{3} \mathrm{O}_{4}\right)$ and/or maghemite $\left(\gamma-\mathrm{Fe}_{2} \mathrm{O}_{3}\right), 3=$ lepidocrocite $(\gamma-\mathrm{FeOOH}), 4=$ wuestite $(\mathrm{FeO})$.

Figure 8: Fe $2 p$ XPS analysis of commercialised ZVI particles.

Figure 9: Normalised Fe K-edge $\mathrm{k}^{3}$-weighted EXAFS of the 5 commercial nZVI/ZVI products tested. Dotted lines show the best 4-component linear combination fit of reference spectra as documented in Table 5.

Figure 10: Fourier transformed radial distribution functions (RDFs) of the five samples and an iron metal foil. The black lines in Figure $X$ represent the sample data and the red dotted curves represent the non-linear fitting results of the EXAFS data. 
Figure 1

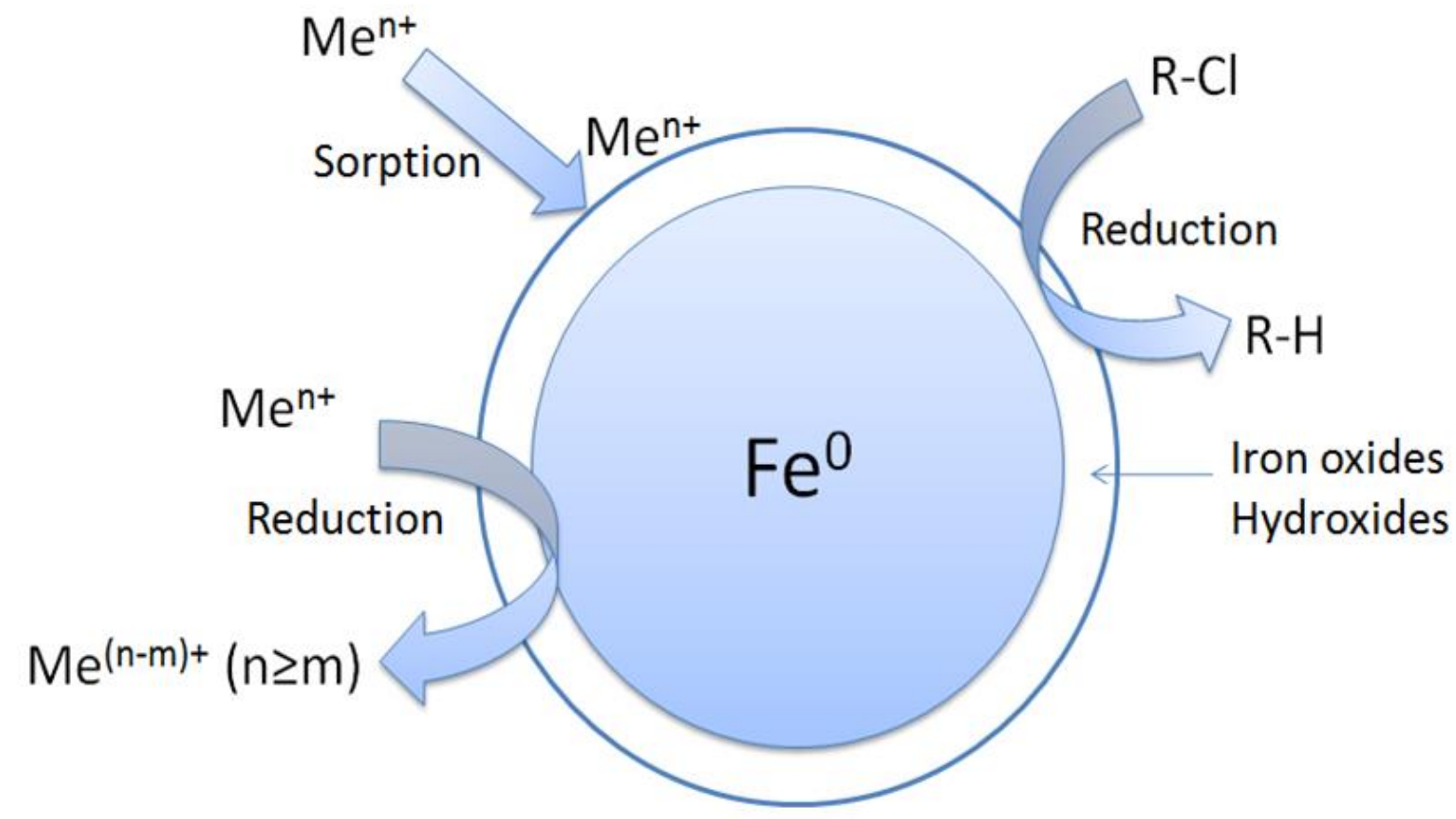


Figure 2

a)

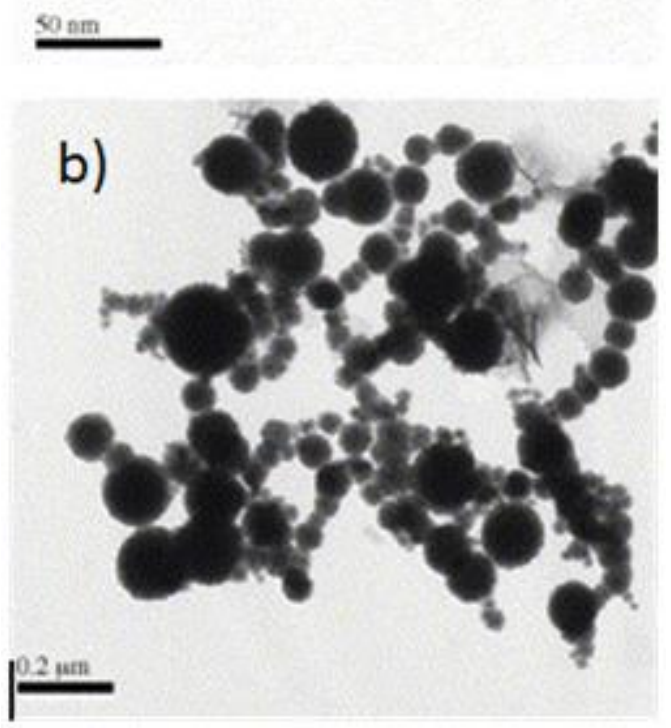

c) 
Figure 3
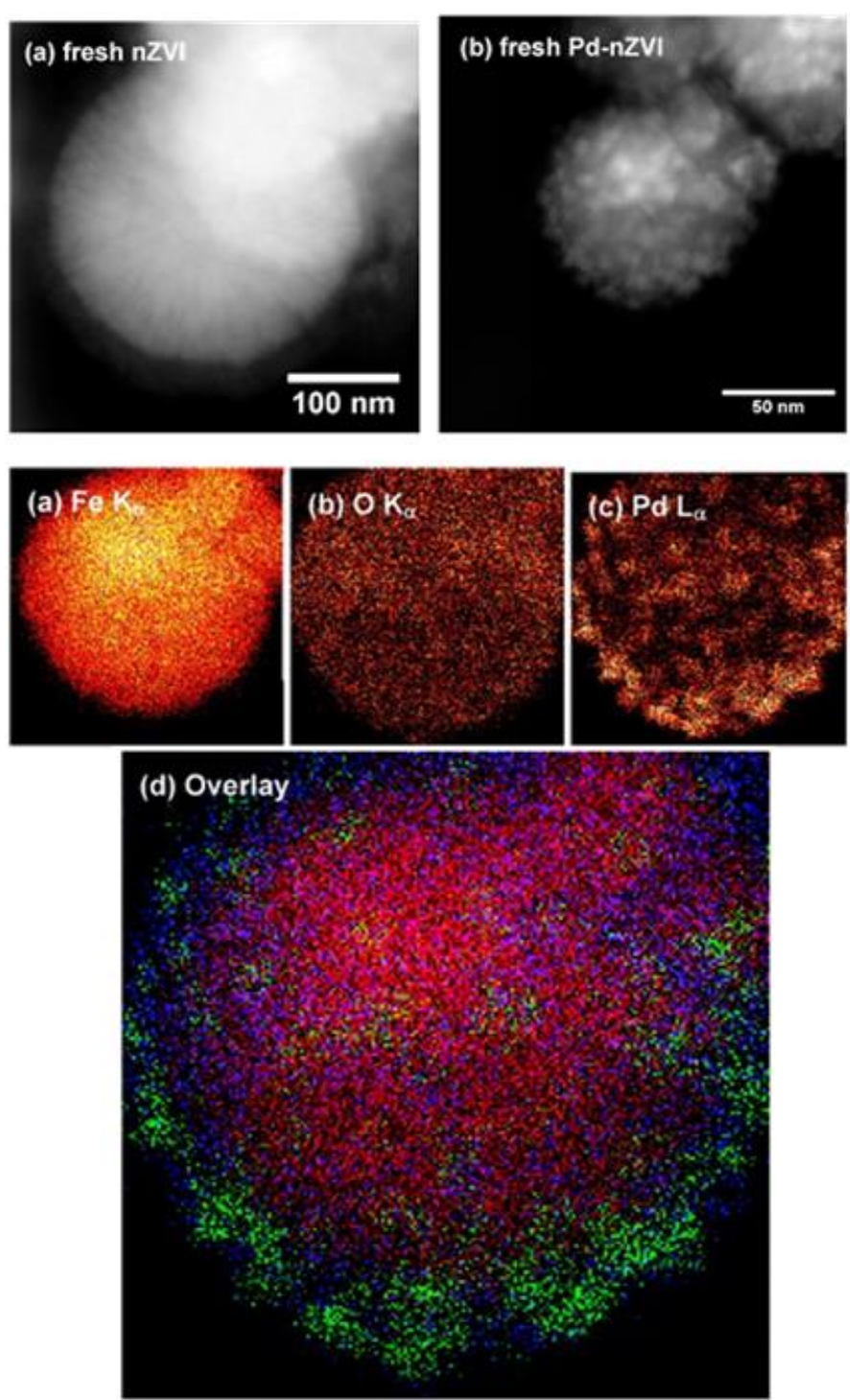
Figure 4
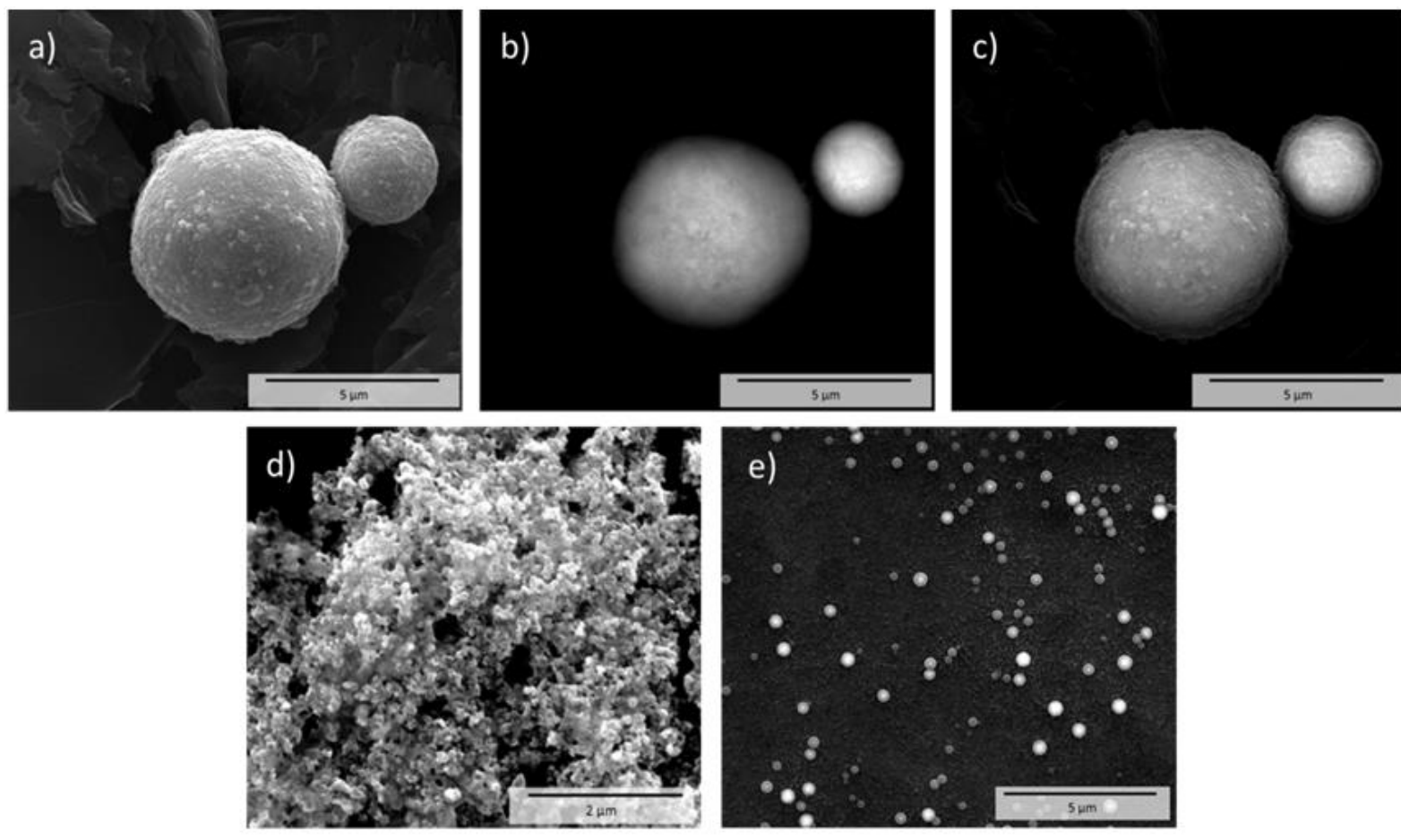

Figure 5

a)

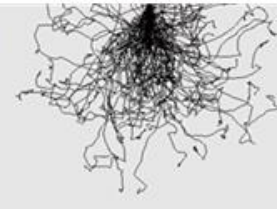

b)

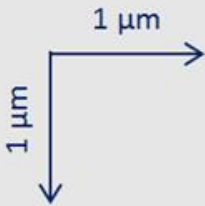

c)

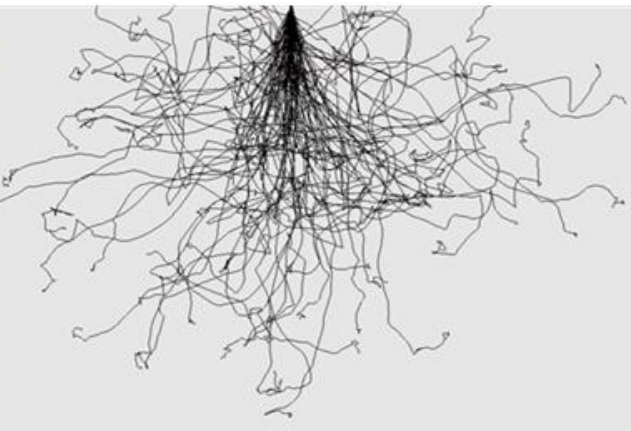


Figure 6

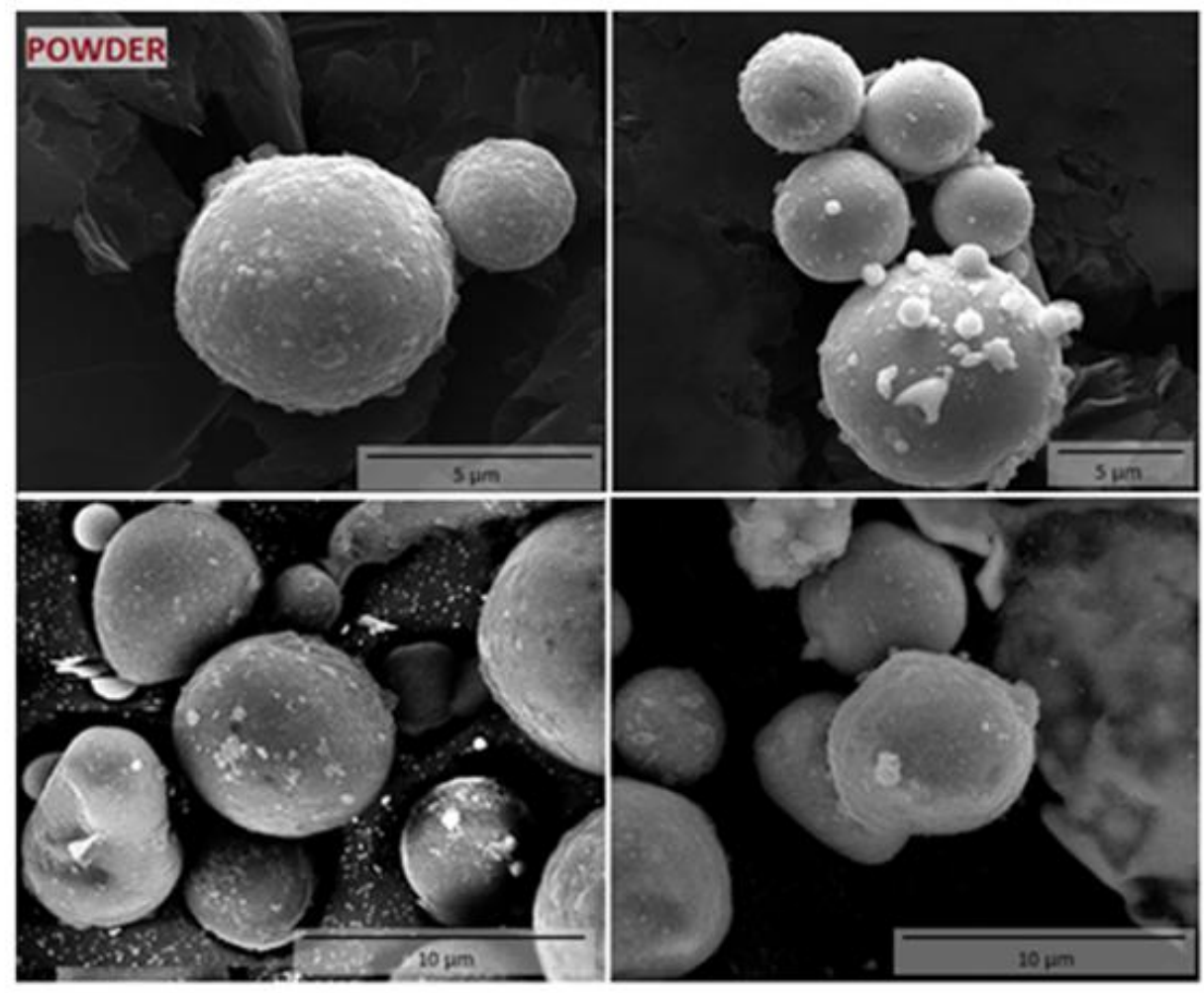

a)

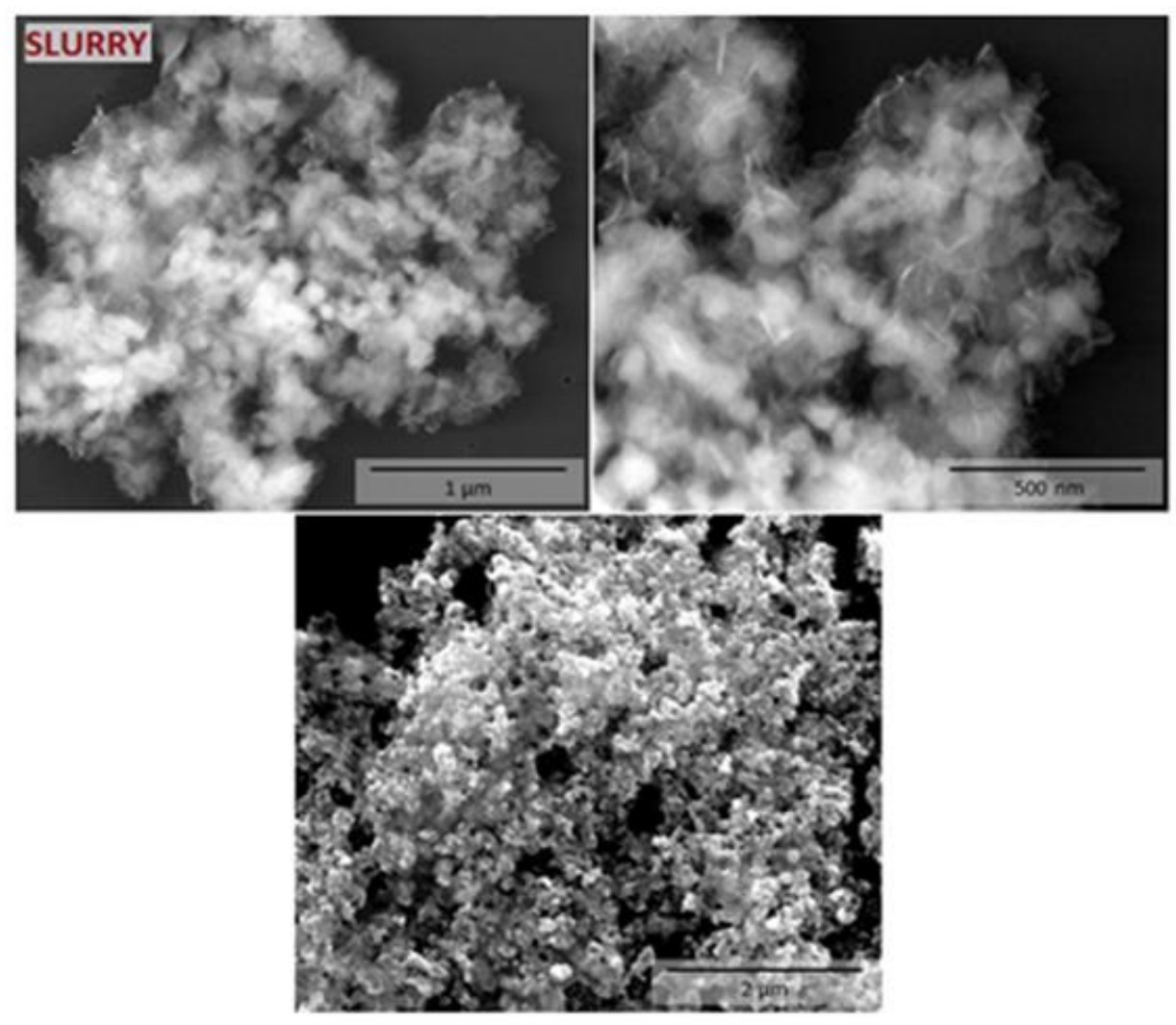

b) 
Figure 7

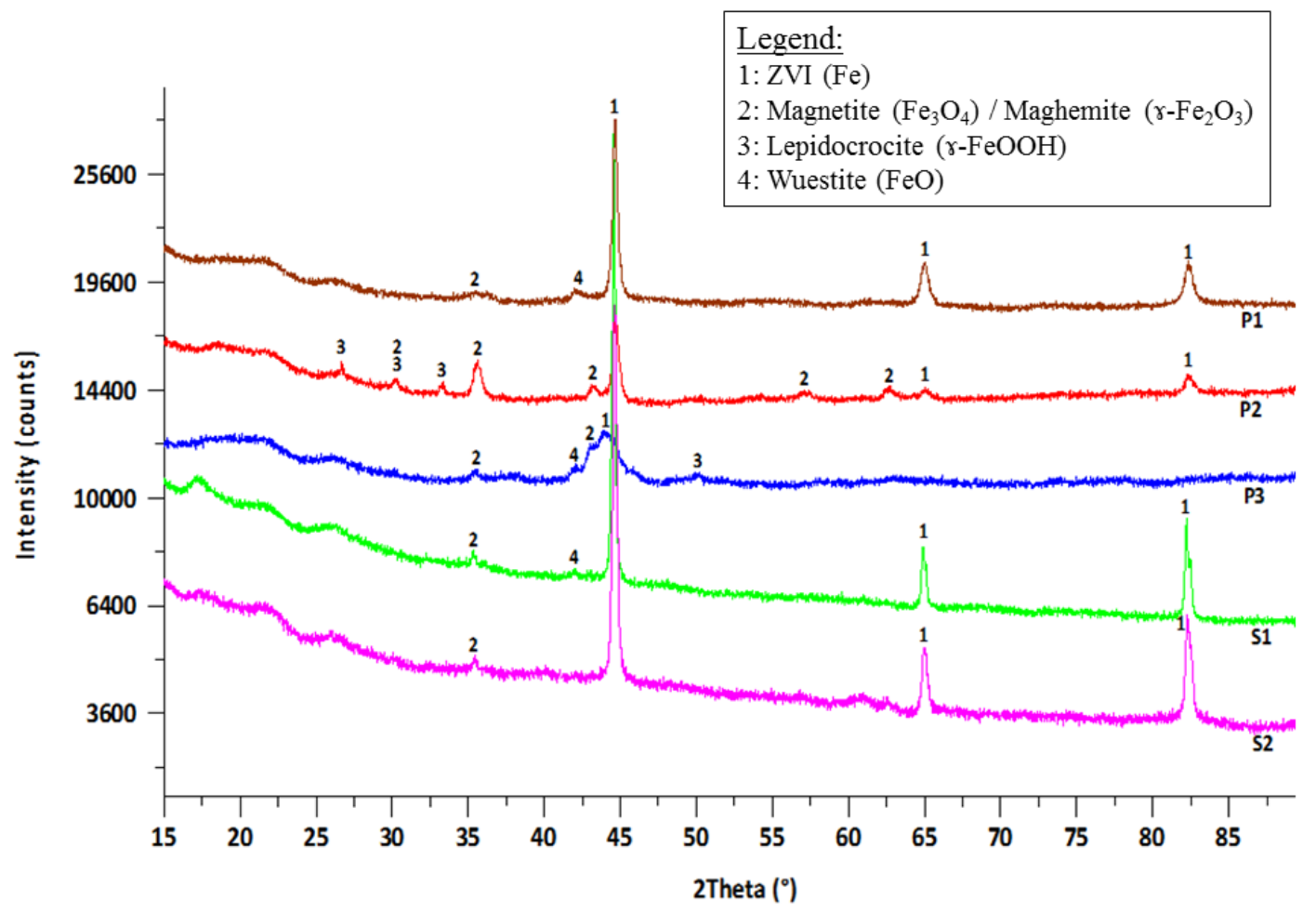

Figure 8

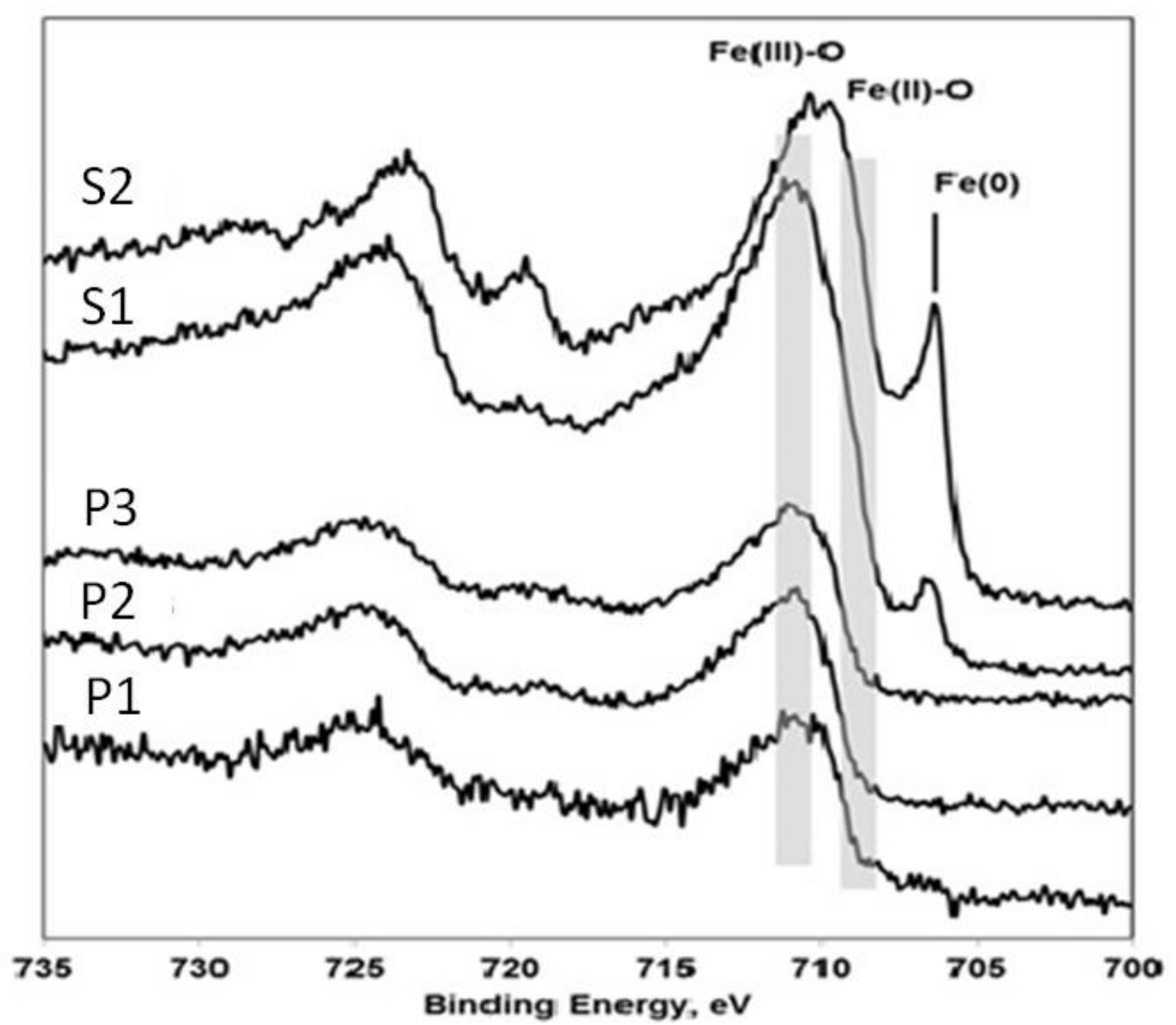


Figure 9

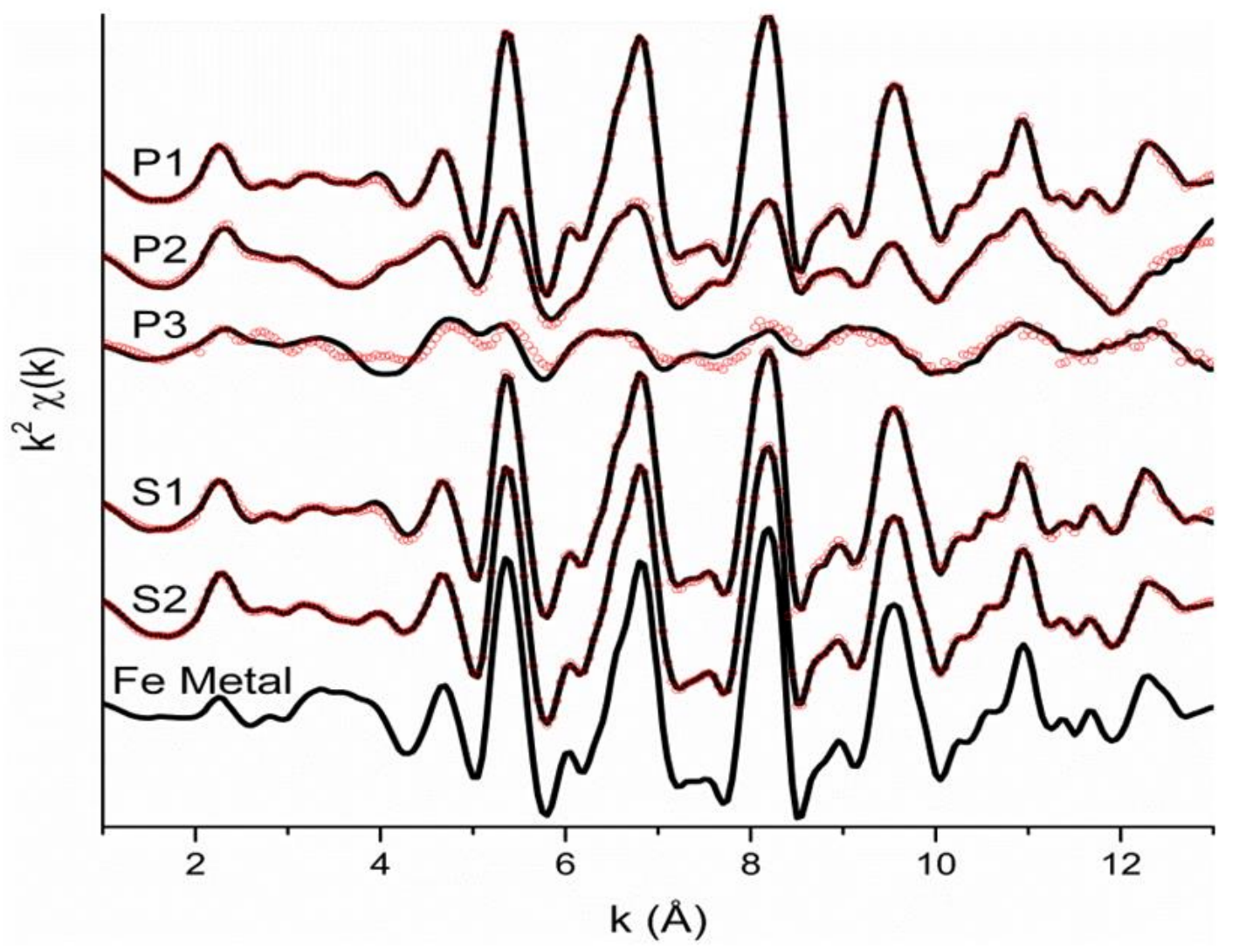

Figure 10

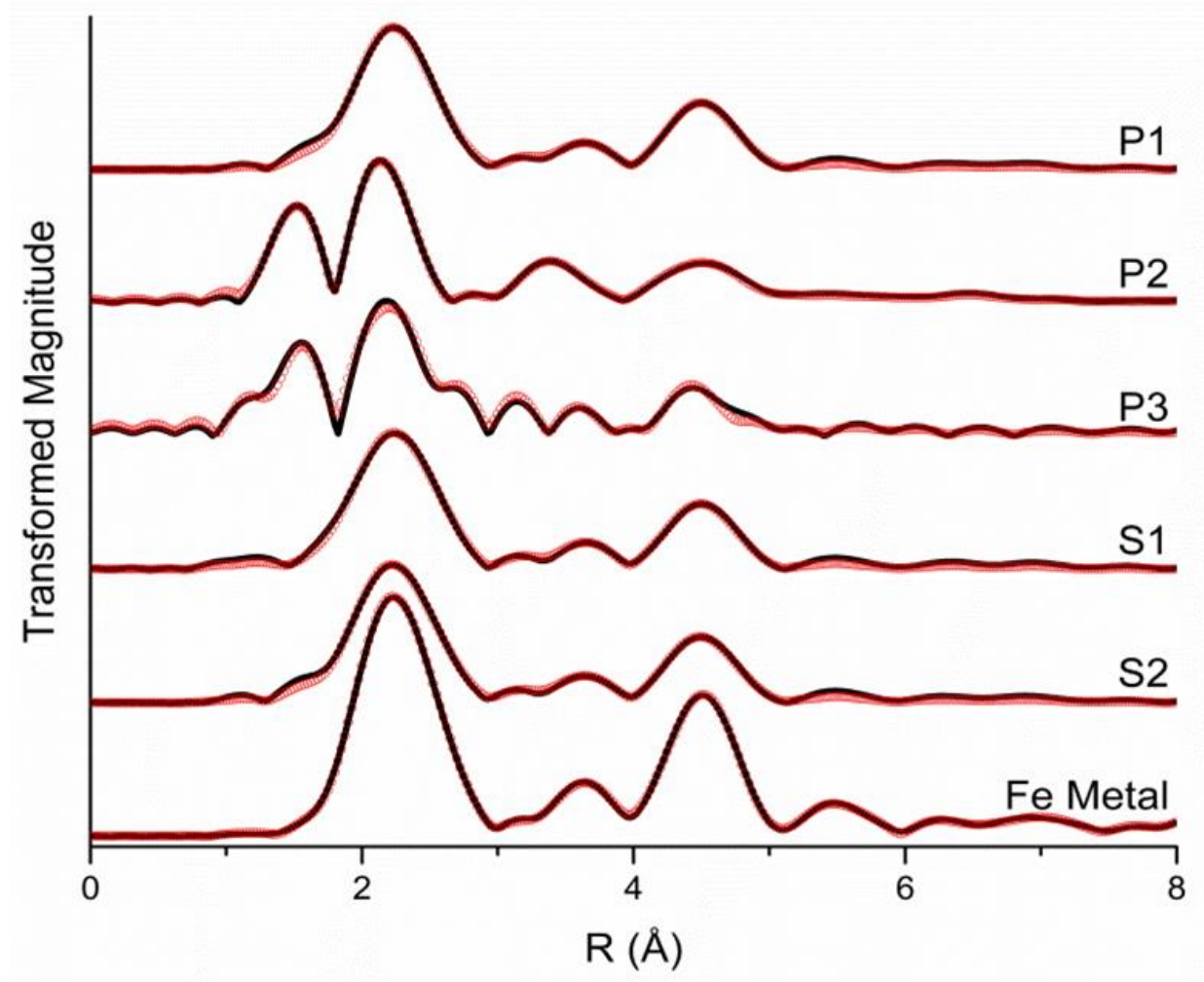

